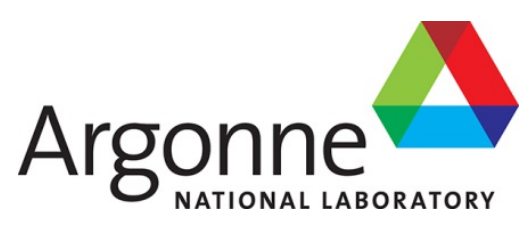

ANL/NE-16/17, Rev. 1

\title{
Quality Assurance Program Plan for SFR Metallic Fuel Data Qualification
}

Nuclear Engineering Division 


\begin{abstract}
About Argonne National Laboratory
Argonne is a U.S. Department of Energy laboratory managed by UChicago Argonne, LLC under contract DE-AC02-06CH11357. The Laboratory's main facility is outside Chicago, at 9700 South Cass Avenue, Argonne, Illinois 60439. For information about Argonne and its pioneering science and technology programs, see www.anl.gov.
\end{abstract}

\title{
DOCUMENT AVAILABILITY
}

Online Access: U.S. Department of Energy (DOE) reports produced after 1991 and a growing number of pre-1991 documents are available free at OSTI.GOV (http://www.osti.gov/), a service of the U.S. Dept. of Energy's Office of Scientific and Technical Information

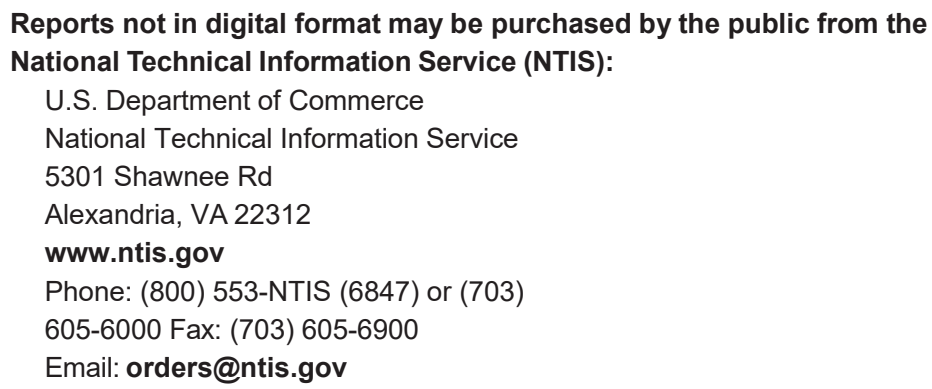

Reports not in digital format are available to DOE and DOE contractors from the Office of Scientific and Technical Information (OSTI):

U.S. Department of Energy

Office of Scientific and Technical Information

P.O. Box 62

Oak Ridge, TN 37831-0062

www.osti.gov

Phone: (865) 576-8401

Fax: (865) 576-5728

Email: reports@osti.gov

\section{Disclaimer}

This report was prepared as an account of work sponsored by an agency of the United States Government. Neither the United States Government nor any agency thereof, nor UChicago Argonne, LLC, nor any of their employees or officers, makes any warranty, express or implied, or assumes any legal liability or responsibility for the accuracy, completeness, or usefulness of any information, apparatus, product, or process disclosed, or represents that its use would not infringe privately owned rights. Reference herein to any specific commercial product, process, or service by trade name, trademark, manufacturer, or otherwise, does not necessarily constitute or imply its endorsement, recommendation, or favoring by the United States Government or any agency thereof. The views and opinions of document authors expressed herein do not necessarily state or reflect those of the United States Government or any agency thereof, Argonne National Laboratory, or UChicago Argonne, LLC. 
ANL/NE-16/17, Rev. 1

\section{Quality Assurance Program Plan for SFR Metallic Fuel Data Qualification}

prepared by

Timothy Benoit

Argonne National Laboratory

May 26, 2019 
ANL/NE-16/17, Rev. 1

\section{Quality Assurance Program Plan for SFR Metallic Fuel Data Qualification}

Argonne National Laboratory

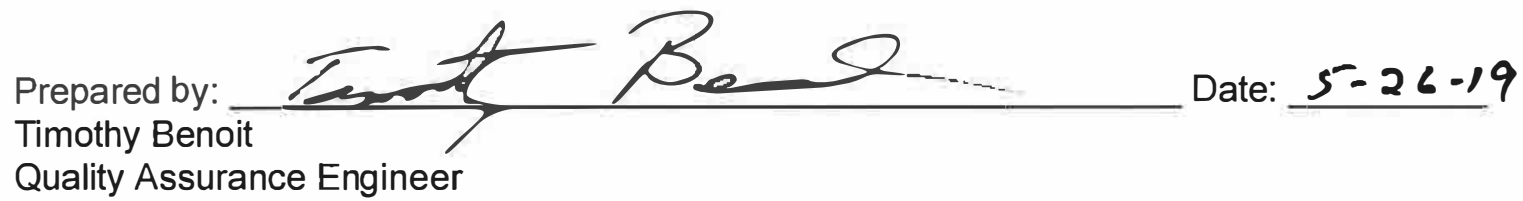

Reviewed by: Date: $5-29-19$ Kun Mo

Technical Lead

Approved by:

Abdellatif Yacout

Fuel Development and Qualification Manager

Date: $5-30-19$ 


\section{EXECUTIVE SUMMARY}

This document contains an evaluation of the applicability of the current Quality Assurance Standards from the American Society of Mechanical Engineers Standard NQA-1 (NQA-1) criteria and identifies and describes the quality assurance process(es) by which attributes of historical, analytical, and other data associated with sodium-cooled fast reactor [SFR] metallic fuel will be evaluated. This process is being instituted to facilitate validation of data to the extent that such data may be used to support future licensing efforts associated with advanced reactor designs. The initial data to be evaluated under this program were generated during the US Integral Fast Reactor program between 1984-1994, where the data includes, but is not limited to, research and development data and associated documents, test plans and associated protocols, operations and test data, technical reports, and information associated with past United States Nuclear Regulatory Commission reviews of SFR designs.

It is recognized that managing the data generated by large research and development projects presents a significant challenge for retaining data integrity and availability. American Society of Mechanical Engineers Standard NQA-1 (NQA-1) 2008/2009a provides appropriate requirements for this plan. 


\section{POLICY STATEMENT}

The Argonne National Laboratory (ANL) legacy metallic fuel data qualification program collects, maintains, and qualifies metallic fuel data generated throughout the US sodium cooled fast reactor program (SFR). The intended end users of the data qualified under this program must satisfy nuclear plant licensing regulations and standards. Accordingly, ANL established a Quality Assurance Program Plan (QAPP) for legacy metallic fuel data using the standards of ASME NQA-1-2008/2009. In some cases, specific provisions and measures have been prepared to meet some aspects of 10CFR50 Appendix B.

The QAPP is the top-level policy document that establishes the way in which quality is achieved in the SFR legacy fuel data. Implementing documents prescribe more detailed responsibilities and requirements and define the organizational interfaces involved within the scope of the QAPP. 
REVISION LOG

\begin{tabular}{|c|c|c|c|}
\hline Rev. & Date & $\begin{array}{c}\text { Affected } \\
\text { Pages }\end{array}$ & Revision Description \\
\hline 1 & $5 / 25 / 2019$ & All & $\begin{array}{l}\text { Added Policy Statement } \\
\text { Requirements } 10,11,12 \text {, and } 14 \text { was changed } \\
\text { to "do not apply" }\end{array}$ \\
\hline & & & \\
\hline & & & \\
\hline & & & \\
\hline & & & \\
\hline & & & \\
\hline & & & \\
\hline & & & \\
\hline & & & \\
\hline & & & \\
\hline & & & \\
\hline & & & \\
\hline & & & \\
\hline & & & \\
\hline & & & \\
\hline & & & \\
\hline & & & \\
\hline & & & \\
\hline & & & \\
\hline
\end{tabular}




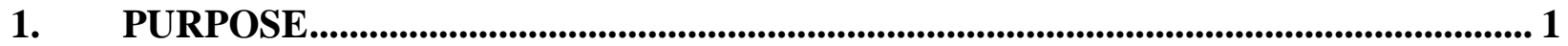

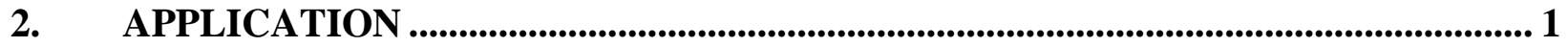

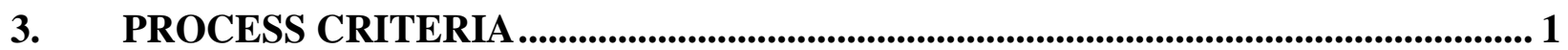

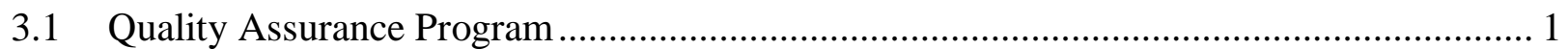

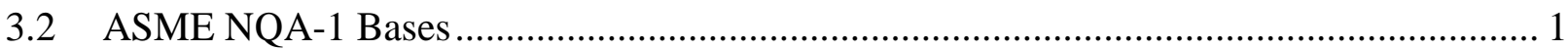

3.2.1 Requirement 1, "Organization" ...................................................................... 3

3.2.2 Requirement 2, "Quality Assurance Program(s)" ................................................... 4

3.2.3 Requirement 3, "Design Control"....................................................................... 5

3.2.4 Requirement 4, "Procurement Document Control" .................................................. 5

3.2.5 Requirement 5, "Instructions, Procedures, and Drawings" ....................................... 5

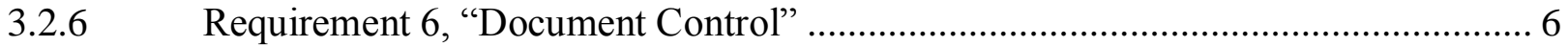

3.2.7 Requirement 7, "Control of Purchased Items and Services" .................................... 7

3.2.8 Requirement 8, "Identification and Control of Items" ............................................ 8

3.2.9 Requirement 9, "Control of Special Processes" ...................................................... 8

3.2.10 Requirement 10, "Inspection" .................................................................... 8

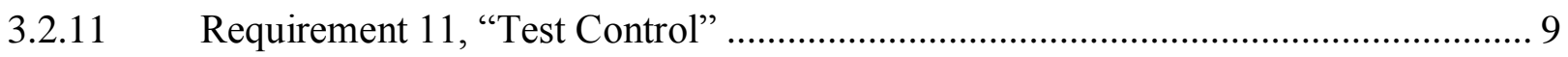

3.2.12 Requirement 12, "Control of Measuring and Test Equipment"............................... 9

3.2.13 Requirement 13, "Handling, Storage and Shipping" ................................................ 9

3.2.14 Requirement 14, "Inspection, Test and Operating Status" ....................................... 9

3.2.15 Requirement 15, "Control of Nonconforming Items"........................................... 10

3.2.16 Requirement 16, "Corrective Action" ................................................................ 10

3.2.17 Requirement 17, "Quality Assurance Records"..................................................... 10

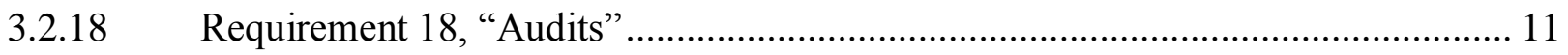

4. VALIDATION PROCESS ........................................................................................ 11

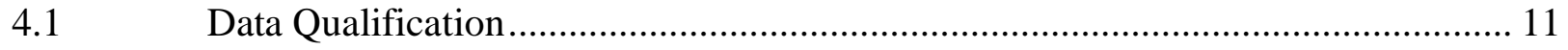

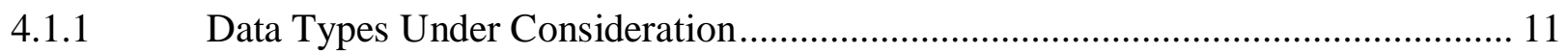

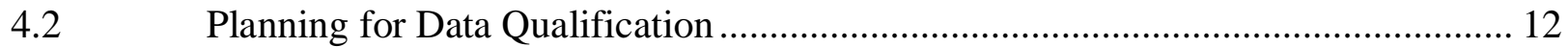

4.2.1 Establishing Evaluation Team ……………….............................................. 12

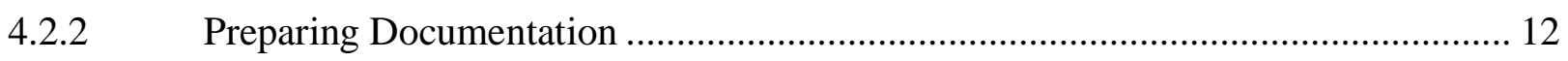

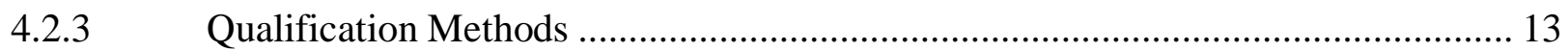

4.2.3.1 Quality Assurance Program Equivalency Method ............................................... 13

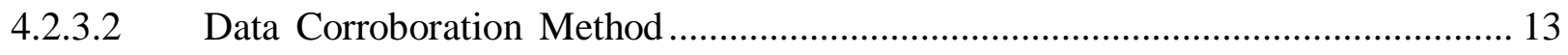

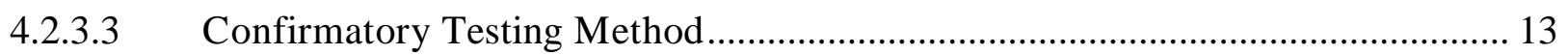

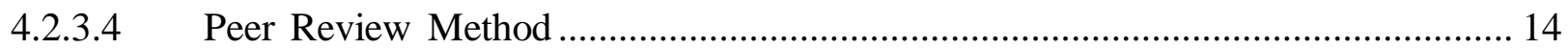

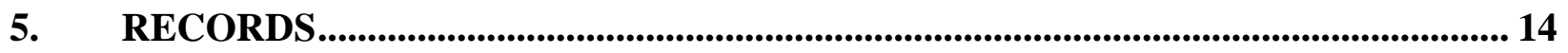

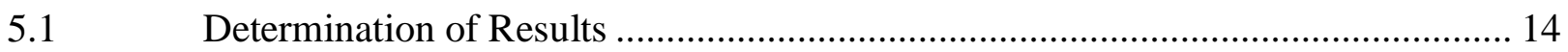

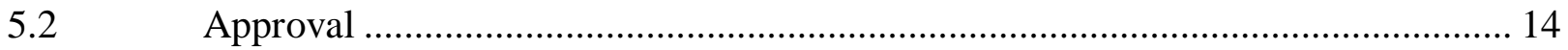

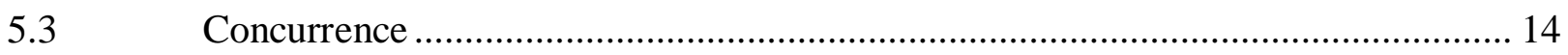




\section{APPENDICES}

Appendix A. Evaluation of Applicability of NQA-1 to SFR Metallic Fuel Historical Data Qualification Process....

\section{ACRONYMS}

DOE Department of Energy

FIPD Fuels Irradiation and Physics Database

M\&TE measuring and test equipment

NARA National Archives and Records Administration

NRC Nuclear Regulatory Commission

QA quality assurance

R\&D research and development

SFR sodium-cooled fast reactor

$\mathrm{V} \& \mathrm{~V} \quad$ verification and validation 


\section{PURPOSE}

Technical information that is to be used in safety design and licensing process requires either traceability or demonstrated equivalence to appropriate quality standards. This document describes an accepted process by which historical fuel testing and evaluation data can be validated for this purpose.

This document implements the applicable portions of both Appendix B, "Quality Assurance Criteria for Nuclear Power Plants and Fuel Reprocessing Plants," to Title 10 of the Code of Federal Regulations (10 CFR) Part 50, "Domestic Licensing of Production and Utilization Facilities," and American Society of Mechanical Engineers (ASME) NQA-1-2008, "Quality Assurance Requirements for Nuclear Facility Applications," with 1a-2009 Addenda, as endorsed by NRC Regulatory Guide (RG) 1.28, Revision 4, "Quality Assurance Program Criteria (Design and Construction)", relevant to the project.

\section{APPLICATION}

The validation process described herein involves recovery of documentation of the quality standards and ancillary documentation (i.e. calibration data and/or procedures, instrumentation and process qualification, in-place quality control, etc.) that were applied during the time tests, measurements, and examinations were performed and post-irradiation fuel performance, quality, and integrity data were generated. This process may include processes such as design control; control of instructions, procedures, drawings; test control; training and qualification; measuring and test equipment control; and review of records and/or other information pertinent to demonstrating the quality of currently available data and information. In the event that retrievable information is insufficient, the process may also involve expert review of the data and/or re-testing or related testing where available. Corroborative testing may be appropriate if such capability exists. The overall qualification of historic data and processes utilize a process that follows criteria as defined in NQA-1, 2008, Part III, subpart 3.3, Appendix 3.1.

\section{PROCESS CRITERIA}

\subsection{Quality Assurance Program}

The Argonne Quality Assurance Program Plan (Argonne QAPP) is the QA program approved by the DOE for Argonne and commits to NQA-1 to implement DOE orders and regulations. It contains provisions allowing departments within Argonne to implement QA program plans for specific activities so long as they conform to the Argonne QAPP. This QAPP for SFR Metallic Fuel Data Qualification conforms to and relies on the Argonne QAPP to implement some aspects of NQA-1, as identified in Appendix B

\subsection{ASME NQA-1 Bases}

All activities associated with the data qualification processes are to be performed in accordance with the NQA-1 criteria identified as applicable in Appendix A "Evaluation of Applicability of NQA-1 to SFR Metallic Fuel Historical Data Qualification Process". The applicable criteria are further specified in the following sections of this document including the controls that will 
be utilized in execution of this qualification process. Software will be controlled in accordance with NQA-1-2009 addenda. The validation process will be performed to one or more of the methods outlined in NQA-1, 2008, Part III, Subpart 3.3 Section 3.1, "Guidance on Qualification of Existing Data." In addition to the execution of the data qualification process outlined in this document, part of the data qualification process will involve the establishment of quality processes, procedures and operations associated with data qualification. Where possible, NQA-1 compliant controls will be documented as to the activities associated with the historical data/experiments. All available documentation from the past tests, and the qualification activities conducted at the time of testing, will be reviewed, controlled, and maintained in accordance with requirements applicable at the time of the activity.

Not all of the requirements listed below may be applicable to this process and project. Where a requirement is not applicable it is noted; when a requirement may apply at a future time, that possibility is addressed.

This document implements the applicable requirements of which were used for guidance:

- 10 CFR 830, "Nuclear Safety Management," Subpart A, "Quality Assurance Requirements" (QA Rule). The QA Rule requires DOE contractors who conduct activities or provide items or services that affect, or may affect, the safety of DOE nuclear facilities to develop and maintain a QAP that implements 10 criteria specified in the rule.

- DOE Order 414.1D, “Quality Assurance” (QA Order). The QA Order requires all DOE contractors to develop and maintain a QAP, which implements 10 criteria specified in the order.

- American Society of Mechanical Engineers (ASME) NQA-1-2008

- American Society of Mechanical Engineers (ASME) NQA-1-1a-2009 Addenda

- Argonne Quality Assurance Program Plan (QAPP) Rev. 8

- Argonne National Laboratory Software Quality Assurance Plan (SQAPP) Rev. 0

Reference materials reviewed for the development of this document include:

- PDD-172 "Next Generation Nuclear Plant Quality Assurance Program Description” (INL)

- AFP-AP-04 “Qualification of Unqualified Data” Revision 01-24-16

- NUREG - 1298, “Qualification of Existing Data for High- Level Nuclear Waste Repositories"

- INL/EXT-15-35805, “Guidance on Evaluating Historic Technology Information for Use in Advanced Nuclear Licensing" Revision 0 


\subsubsection{Requirement 1, "Organization"}

Responsibilities for the establishment and implementation of the quality assurance program shall be defined. The organizational structure, functional responsibilities, levels of authority, and lines of communications for activities affecting quality shall be documented."

\section{Implementation}

An Organization Chart listing key personnel, reporting structures and responsibilities has been established.

\section{Roles and Responsibilities}

Functional responsibilities and levels of authority are identified in roles, responsibilities, accountabilities, and authorities documents (R2A2s), which are developed for each management position. Specific responsibilities for implementing ANL QAP requirements are identified in the associated implementing procedures.

The review process may employ several different individuals during the course of reviews. The primary roles are defined below.

\section{Project Manager}

Provides overall management direction, defines roles and responsibilities, delegates authorities, and enforces accountabilities for the organization.

Ensures that the appropriate process controls are formally defined for the execution of project work.

\section{Technical Lead}

Establishes, in coordination with the Project Manager, the structure, processes, and responsibilities of the review team, which includes developing and executing work packages to complete project milestones.

Provides technical direction, coordination, problem resolution, and oversight of Project design and regulatory activities to ensure that the approach, scope, and outcomes of these activities are consistent with the technical requirements (e.g., functional and operational requirements) of the Project.

\section{QA Engineer}

Verifies the development and implementation of this QA Plan.

Assures compliance with regulatory requirements and procedures through audits and monitoring technical reviews and organization processes to ensure conformance to requirements. 
Assists in identifying and interpreting the QA requirements and standards that apply to the process.

Assists the Project Manager in developing and maintaining QAPD documentation, including implementing procedures.

\section{Subject Matter Expert}

Provide input and review data to determine acceptability of past data/experiments. Provide expertise in the data reviews to assure processes were adequate for the activity performed.

\subsubsection{Requirement 2, "Quality Assurance Program(s)"}

NQA-1 states: "A documented quality assurance program shall be planned, implemented, and maintained in accordance with this Part (Part I), or portions thereof. The program shall identify the activities and items to which it applies. The program shall provide control over activities affecting quality to an extent consistent with their importance. The program shall include monitoring activities against acceptance criteria in a manner sufficient to provide assurance that the activities affecting quality are performed satisfactorily. The program shall be established at the earliest time consistent with the schedule for accomplishing the activities."

\section{Implementation}

QA and inspection personnel have the responsibility and authority to stop work in progress if it is not being done in accordance with approved procedures or where safety may be jeopardized. This extends to offsite work performed by suppliers that furnish safety-related materials and services to ANL. All ANL personnel have the authority to initiate a "Stop Work Order to resolve a condition that is potentially unsafe or adverse to quality, and to declare a stop work action if the condition is not readily fixable.

The applicability of NQA-1-2008, 1a-2009 requirements to technology development is determined using a technology life-cycle approach identified in NQA-1-2008, 1a-2009, Part III, Subpart 3.3, Appendix 3.1 "Guidance on Qualification of Existing Data." The rigor with which the applicable QAP requirements are applied is then determined through a formal risk-based process that considers probability and consequence of failure. To ensure defensible data and records used in design and licensing, technology development resulting in data used in safetyrelated design and licensing activities is subject to all applicable NQA-1-2008, 1a-2009 requirements.

Management of those organizations implementing this document, or portions thereof, shall assess the adequacy of that part of the program for which they are responsible to assure its effective implementation at least once each year or at least once during the life of the activity, whichever is shorter. The period for assessing the process during the operations phase may be extended to once every two years.

This document constitutes the Quality Assurance Program for data qualification activities, including the controls of historical data being reviewed. As part of these activities, QA 
program(s) in place, as discussed above, will provide a framework for the overall data qualification process. Documentation of QA programs in place when the work was performed is integral to meeting this requirement. All programmatic controls in place at the time of data generation will be identified in the review process. In general, the program requirements specified herein will be discussed in either ANL implementing procedures or Data Qualification specific procedures.

\subsubsection{Requirement 3, "Design Control"}

NQA-1 states: "The design shall be defined, controlled, and verified. Design inputs shall be specified on a timely basis and translated into design documents. Design interfaces shall be identified and controlled. Design adequacy shall be verified by individuals other than those who designed the item or computer program. Design changes shall be governed by control measures commensurate with those applied to the original design."

\section{Implementation}

Design in the context of this quality assurance plan means the conceptualization and development of processes to review and evaluate data. These design activities are realized in the development, review, approval, and control of documents addressed by NQA-1-2008, 1a-2009 Requirements 5 and 6.

\section{Data Quality Objectives}

Part of the input for the design and execution of these processes will be data quality objectives as defined and described by EPA QA/G-4 Guidance on Systematic Planning Using the Data Quality Objectives Process (EPA/240/B-06/001). This iterative process engages intermediate and final customers for the output of the evaluation process in the identification and development of guidance and criteria for the acceptability of the final products.

\subsubsection{Requirement 4, "Procurement Document Control"}

NQA-1 states "Applicable design bases and other requirements necessary to assure adequate quality shall be included or referenced in documents for procurement of items and services. To the extent necessary, procurement documents shall require Suppliers to have a quality assurance program consistent with the applicable requirements of this Standard."

\section{Implementation}

This Requirement does apply when quality-related procurements are planned for the evaluation effort. All work will be reviewed and approved by ANL Management to assure compliance with these requirements.

\subsubsection{Requirement 5, "Instructions, Procedures, and Drawings"}

NQA-1 states: "Activities affecting quality and services shall be prescribed by and performed in accordance with documented instructions, procedures, or drawings that include or reference 
appropriate quantitative or qualitative acceptance criteria for determining that prescribed activities have been satisfactorily accomplished. The activity shall be described to a level of detail commensurate with the complexity of the activity and the need to assure consistent and acceptable results. The need for, and level of detail in, written procedures or instructions shall be determined based upon complexity of the task, the significance of the item or activity, work environment, and worker proficiency and capability (education, training, experience)".

\section{Implementation}

Procedures will be fully in place, and will undergo consistent refinement, for the performance of the data qualification. Current procedures address the applicable content of procedures as described in the Introduction to Part II of NQA-1-2008, 1a-2009. In addition, procedures governing tests, inspections, operational activities, and maintenance will include, as applicable, initial conditions and prerequisites for the performance of the activity.

In establishing procedural controls, ANL commits to compliance with NQA-1-2008, 1a-2009, Requirement 5.

\subsubsection{Requirement 6, "Document Control"}

NQA-1 states: "The preparation, issue, and change of documents that specify quality requirements or prescribe activities affecting quality such as instructions, procedures, and drawings shall be controlled to ensure that correct documents are being employed. Such documents, including changes thereto, shall be reviewed for adequacy and approved for release by authorized personnel."

\section{Implementation}

ANL has established the necessary measures and governing procedures to control the preparation of, issuance of, and changes to documents that specify quality requirements or prescribe how activities affecting quality, including organizational interfaces, are controlled to ensure that correct documents are being employed. Data qualification documents will be controlled by the ANL document control procedures meeting DOE requirements. The following controls (including electronic systems used to make documents available) are applied to documents and changes thereto:

A. Identification of controlled documents

B. Specified distribution of controlled documents for use at the appropriate location

C. A method to identify the correct document (including revision) to be used and control of superseded documents

D. Identification of individuals responsible for preparation, review, approval, and distribution of controlled documents 
E. Review of controlled documents for adequacy, completeness, and approval prior to distribution

F. A method for providing feedback from users to improve procedures and work instructions

G. Coordinating and controlling interface documents and procedures.

The types of documents to be controlled may include:

A. Drawings such as design, construction, installation, and as-built drawings

B. Engineering calculations

C. Design specifications

D. Purchase orders and related documents

E. Vendor-supplied documents

F. Audit, surveillance, and quality verification/inspection procedures

G. Inspection and test reports

H. Instructions and procedures for activities covered by this QAPD, including R\&D activities, design, construction, installation, operation (including normal and emergency operations), maintenance, calibration, and routine testing

I. Technical specifications

J. Nonconformance and corrective action reports.

Documents are reviewed for adequacy by qualified persons other than the preparer. Procedures for any activities associated with this process are also reviewed by the organization responsible for quality verification to ensure QA measures have been appropriately applied. The documented review signifies concurrence.

Changes to documents, other than those defined in implementing procedures as minor changes, are reviewed and approved by the same organizations that performed the original review and approval unless other organizations are specifically designated.

Procedures and other documents used for data evaluation qualification activities will be controlled as required by approved procedures.

\subsubsection{Requirement 7, "Control of Purchased Items and Services"}

NQA-1 states: "The procurement of items and services shall be controlled to ensure conformance with specified requirements. Such control shall provide for the following as appropriate: source 
evaluation and selection, evaluation of objective evidence of quality furnished by the Supplier, source inspection, audit, and examination of items or services upon delivery or completion."

\section{Implementation}

Applicable, source inspection, audit, and/or examination of items or services may be used. Provisions are made for accepting purchased items and services, such as source verification, receipt inspection, pre- and post-installation tests, certificates of conformance, and document reviews (including Certified Material Test Report/Certificate). Acceptance actions/documents should be established by the purchaser with appropriate input from the supplier and be completed to ensure that procurement, inspection, and test requirements, as applicable, have been satisfied before relying on the item to perform its intended safety function.

\subsubsection{Requirement 8, "Identification and Control of Items"}

NQA-1 states: "Controls shall be established to assure that only correct and accepted items are used or installed. Identification shall be maintained on the items or in documents traceable to the items, or in a manner that assures that identification is established and maintained.

\section{Implementation}

This Requirement is not applicable to data evaluation activities.

\subsubsection{Requirement 9, "Control of Special Processes"}

NQA-1 states "Special processes that control or verify quality, such as those used in welding, heat treating, and nondestructive examination, shall be performed by qualified personnel using qualified procedures in accordance with specified requirements."

\section{Implementation}

This Requirement is not applicable to data evaluation activities.

\subsubsection{Requirement 10, "Inspection"}

NQA-1 states: "Inspections required to verify conformance of an item or activity to specified requirements or continued acceptability of items in service shall be planned and executed. Characteristics subject to inspection and inspection methods shall be specified. Inspection results shall be documented. Inspection for acceptance shall be performed by qualified persons other than those who performed or directly supervised the work being inspected."

\section{Implementation}

This Requirement is not applicable to data qualification. 


\subsubsection{Requirement 11, "Test Control"}

NQA-1 states: "Tests required to collect data such as for siting or design input, to verify conformance of an item or computer program to specified requirements, or to demonstrate satisfactory performance for service shall be planned and executed. Characteristics to be tested and test methods to be employed shall be specified. Test results shall be documented and their conformance with test requirements and acceptance criteria shall be evaluated."

\section{Implementation}

The Requirement is not applicable to data qualification activities. See ANL SQAPP for test control as applied to software.

\subsubsection{Requirement 12, "Control of Measuring and Test Equipment"}

NQA-1 states: "Tools, gages, instruments, and other measuring and test equipment used for activities affecting quality shall be controlled, calibrated at specific periods, adjusted, and maintained to required accuracy limits."

\section{Implementation}

The Requirement is not applicable to data qualification activities.

\subsubsection{Requirement 13, "Handling, Storage and Shipping"}

NQA-1 states: "Handling, storage, cleaning, packaging, shipping, and preservation of items shall be controlled to prevent damage or loss and to minimize deterioration. These activities shall be conducted in accordance with established work and inspection instructions, drawings, specifications, shipment instructions, or other pertinent documents or procedures specified for use in conducting the activity."

\section{Implementation}

This Requirement is not applicable to data evaluation activities.

\subsubsection{Requirement 14, "Inspection, Test and Operating Status"}

NQA-1 states: "The status of inspection and test activities shall be identified either on the items or in documents traceable to the items where it is necessary to ensure that required inspections and tests are performed and to ensure that items that have not passed the required inspections and tests are not inadvertently installed, used, or operated."

\section{Implementation}

The Requirement is not applicable to data qualification activities, beyond Laboratory and Division policies and procedures, and no additional measures are required. 


\subsubsection{Requirement 15, “Control of Nonconforming Items"}

NQA-1 states: "Items that do not conform to specified requirements shall be controlled to prevent inadvertent installation or use. Controls shall provide for identification, documentation, evaluation, segregation when practical, and disposition of nonconforming items, and for notification to affected organizations."

\section{Implementation}

The Requirement does apply to data qualification activities.

\subsubsection{Requirement 16, "Corrective Action"}

NQA-1 states: "Conditions adverse to quality shall be identified promptly and corrected as soon as practicable. In the case of a significant condition adverse to quality, the cause of the condition shall be determined and corrective action taken to preclude recurrence. The identification, cause, and corrective action for significant conditions adverse to quality shall be documented and reported to appropriate levels of management. Completion of corrective actions shall be verified."

\section{Implementation}

ANL has established an issues management and tracking program and process that includes the necessary measures and laboratory wide procedures to promptly identify, control, document, classify, and correct conditions adverse to quality. Argonne's issues management process assures that corrective actions are documented and initiated following the determination of conditions adverse to quality in accordance with regulatory requirements and applicable quality standards. ANL implements an electronic "Issues Management and Tracking System". Noncompliance and/or conditions adverse to quality in data evaluation and qualification activities will be controlled as required by these Argonne procedures.

\subsubsection{Requirement 17, “Quality Assurance Records"}

NQA-1 states "The control of quality assurance records shall be established consistently with the schedule for accomplishing work activities. Quality assurance records shall furnish documentary evidence that items or activities meet specified quality requirements. Quality assurance records shall be identified, generated, authenticated, and maintained, and their final disposition specified. Record control requirements and responsibilities for these activities shall be documented."

\section{Implementation}

ANL procedures ensure that sufficient records of items and activities affecting quality are developed, reviewed, approved, issued, used, and revised to reflect completed work. The provisions of such procedures establish the scope of the records retention program for ANL and include requirements for records administration, including receipt, preservation, retention, storage, safekeeping, retrieval, access controls, user privileges, and final disposition in accordance with ANL record management requirements retention requirements. All records 
associated with the Data Qualification, both historical and newly generated will be controlled according to Argonne procedures. Data evaluation and qualification activities will be controlled as required by the Argonne procedures. Records will be stored in accordance with the NQA-1 requirements along with the NARA and Argonne requirements for Federal records retention. Records of activities for R\&D, design, engineering, procurement, manufacturing, construction, inspection and testing, operations, maintenance, modification, and audits and their retention times are defined in Argonne procedures. The records and retention times are based on applicable Regulatory and DOE requirements.

\subsubsection{Requirement 18, "Audits"}

NQA-1 states:" Audits shall be performed to verify compliance to quality assurance program requirements, to verify that performance criteria are met, and to determine the effectiveness of the program. These audits shall be performed in accordance with written procedures or checklists by personnel who do not have direct responsibility for performing the activities being audited. Audit results shall be documented and reported to and reviewed by responsible management. Follow-up action shall be taken where indicated."

\section{Implementation}

An audit history will be maintained for historical data qualification activities. Audits of current qualification activities will be conducted. Self-assessments may be performed in addition.

\section{Subpart 2.7}

Software used in data qualification (as opposed to word-processing or graphical software) will be addressed using the requirements of paragraph 302 Otherwise Acquired Software. A plan and procedure for implementing subpart 2.7 exists under the Argonne QAPP and will be used as needed.

\section{VALIDATION PROCESS}

\subsection{Data Qualification}

The data qualification process outlined in this document is based on American Society of Mechanical Engineers (ASME) Standards NQA-1-2008, "Quality Assurance Requirements for Nuclear Facility Applications," and NQA-1a-2009, Addenda to ASME NQA-1-2008, which provides the fundamental quality assurance requirements as delineated in 10 CFR 50; quality assurance criteria for nuclear power and fuel reprocessing plants.

\subsubsection{Data Types Under Consideration}

1. Type A-Data collected within an applicable, historical, NQA-1 QA program that met specific requirements for data use. Intended use is defined. Data collectors verify that test requirements were met. Independent verification may be used to ensure that all other requirements were met. These data are used by the program to support nuclear materials and facilities design and licensing and are collected within performance testing, out-of-pile, non-destructive and 
destructive materials testing, and experimental verification of the metallic fuel. The qualification of these Type-A supporting data elements must be addressed in the data collection plan and data evaluation and qualification process.

2. Type B-Data collected within an NQA-1 QA program that are not intended or needed to support nuclear materials and facility design and licensing activities. These data are considered for information only.

3. Type C-Data collected outside an NQA-1 QA program or not known that have a defined intended use. Evaluation is required to verify that the controls were in place as part of the data planning, collection, and storage processes that compare to NQA-1 applicable requirements. Data meeting all requirements may be qualified for intended use under an appropriate procedure. Note: Some Historical data may, in part, have been controlled by a ten point Quality program such as DOE Order 414.1, and 10CFR830, subpart A. Those requirements will be reviewed to determine acceptability compared to the 2008/2009 requirements of NQA-1 Part III, subpart 3.3, Appendix 3.1, "Guidance on Qualification of Existing Data".

\subsection{Planning for Data Qualification}

\subsubsection{Establishing Evaluation Team}

An appropriate evaluation team to perform such a validation should consist of, at a minimum, a technical lead, QA engineer, subject matter expert (see def.) (e.g., fuel engineer, safety analysis engineer, design engineer, $R \& D$ research engineer), and project manager. The evaluation team established for the peer review and QA equivalency of the SFR metallic fuel data currently include the following:

- Principal QA engineer

- Project Manager

- $\quad$ Support QA engineer

- Records Support Personal

- SMEs; fuel experts, including experts who were involved in the generation and analysis of the data during the IFR program.

- Data Technical Support Personal

\subsubsection{Preparing Documentation}

The evaluation of each of the analytical processes and associated data are to be documented. A Data Evaluation Form is to be used for this purpose. The Data Evaluation Form provides evidence of the evaluation and also provides a quality record of the evaluation. 


\subsubsection{Qualification Methods}

The four (4) methods available for data validation and their respective descriptions as prescribed in NQA-1, 2008, Part III, Subpart 3.3 Section 3.1, "Guidance on Qualification of Existing Data" are:

\subsubsection{Quality Assurance Program Equivalency Method}

The Quality Assurance Program Equivalency method may be used to determine if the acquisition, development, or processing of data have been performed in accordance with sound technical, administrative practices or procedures that can be demonstrated to generally meet the applicable requirements and guidance of NQA-1. The employed practices or procedures must demonstrate industry-acceptable scientific, engineering or administrative practices or processes with appropriate compliance documentation as defined in data qualification planning. Examples of conditions for which the Quality Assurance Program Equivalency method may be useful include the following:

- data acquisition, collection, or development records, including equipment calibration documentation, and personnel qualification records are available

- documentation of the technical or administrative practices or procedures used to process the data are available

\subsubsection{Data Corroboration Method}

The Data Corroboration method may be used in order to determine if subject matter data comparisons can be shown to substantiate or confirm parameter values. This method may include comparisons of the data to both other sources of qualified data, as well as to sources of other existing data, as defined in data qualification planning. Examples of conditions for which the Data Corroboration method may be useful include the following:

a) a sufficient quantity of corroborating data are available to permit valid statistical comparison with the unqualified data set(s)

b) inferences drawn to corroborate the existing data can be clearly identified, justified, and documented

\subsubsection{Confirmatory Testing Method}

The Confirmatory Testing method may be used when tests can be designed and performed to establish the quality of existing or indeterminate data. Confirmatory Testing also may be used when previous test results are not verifiable as a result of questionable testing methodology or a lack of applicable documentation. Confirmatory test results should demonstrate direct correlation to previous test results, if feasible. However, data extrapolation is acceptable within the limits defined in data qualification planning. Examples of conditions for which the Confirmatory Testing method may be useful include the following:

a) similar test conditions are prescribed 
b) test result correlation or extrapolations are applicable

\subsubsection{Peer Review Method}

The Peer Review Method is used to independently evaluate data to determine if the employed methodology is acceptable; confidence is warranted in the data acquisition or developmental results; or the data have been used in a similar range of applications. Use of the Peer Review method for this purpose should include an evaluation of the data acquisition and development approach, including test plans, to determine the acceptability of the uncertainties associated with the employed data acquisition or development methodology, the adequacy and appropriateness of the interpretations derived from the data, and the extent to which the uncertainties affect the interpretations, conclusions, and overall validity of the data. If the evaluation indicates the uncertainties are unacceptable or the data interpretations are inappropriate, this result should be fully documented. A report documenting the peer review activity should be prepared as defined during data qualification planning and provide for the inclusion of any dissenting conclusions and comments by individual peer reviewers.

\section{RECORDS}

\subsection{Determination of Results}

A final review of evaluation results will be performed and the overall results documented in a Data Evaluation Form. The conclusion of the review will document whether the process and/or individual data set(s) can be deemed equivalent or if open items exist requiring resolution prior to demonstrating equivalency.

\subsection{Approval}

Approval of data evaluation forms will be made by all members of the evaluation team

\subsection{Concurrence}

The project manager will ensure that all decisions are performed by personnel qualified and authorized to evaluate data under prescribed conditions. The project manager should document concurrence with all decisions and report content on the Data Evaluation Form. 


\section{Appendix A: Evaluation of Applicability of NQA-1 to SFR Metallic Fuel Historical Data Qualification Process}

\begin{tabular}{|c|c|}
\hline NQA-1-2008/9 Requirements & Applicability \\
\hline Req. 1 Organization & \\
\hline $\begin{array}{l}\text { Req. 1, } 100 \text { GENERAL } \\
\text { Responsibilities for the establishment and implementation of the quality assurance program shall be defined. The organizational } \\
\text { structure, functional responsibilities, levels of authority, and lines of communications for activities affecting quality shall be } \\
\text { documented. }\end{array}$ & $\begin{array}{l}\text { Applicable as implemented by this } \\
\text { plan. }\end{array}$ \\
\hline $\begin{array}{l}\text { Req. 1, } 200 \text { STRUCTURE AND RESPONSIBILITY } \\
\text { Req. 1, } 201 \text { General } \\
\text { The organizational structure and responsibility assignments shall be such that } \\
\text { (a) senior management establishes overall expectations for effective implementation of the quality assurance program and is } \\
\text { responsible for obtaining the desired end result } \\
\text { (b) quality is achieved and maintained by those assigned responsibility for performing work } \\
\text { (c) quality achievement is verified by those not directly responsible for performing the work } \\
\text { (d) those responsible for assuring that an appropriate quality assurance program has been established and those verifying activities } \\
\text { affecting quality have sufficient authority, direct access to responsible levels of management, organizational freedom, and access to } \\
\text { work to perform this function, including sufficient independence from cost and schedule when opposed to safety function } \\
\text { considerations. These verification functions include the following: } \\
\text { (1) identifying quality problems } \\
\text { (2) initiating, recommending, or providing solutions to quality problems through designated channels } \\
\text { (3) verifying implementation of solutions } \\
\text { (4) assuring that further processing, delivery, installation, or use is controlled until proper disposition of a nonconformance, } \\
\text { deficiency, or unsatisfactory condition has occurred. }\end{array}$ & $\begin{array}{l}\text { Applicable and implemented in } \\
\text { accordance with the Argonne } \\
\text { QAPP. }\end{array}$ \\
\hline $\begin{array}{l}\text { Req. 1, } 202 \text { Delegation Of Work } \\
\text { The individual(s) or organization(s) responsible for establishing and executing a quality assurance program under this Standard may } \\
\text { delegate any or all of the work to others but shall retain responsibility thereof. }\end{array}$ & Not Applicable \\
\hline $\begin{array}{l}\text { Req. 1, } 300 \text { INTERFACE CONTROL } \\
\text { Where more than one organization is involved in the execution of activities, the responsibilities, interfaces, and authority of each }\end{array}$ & Not Applicable \\
\hline
\end{tabular}




\section{Appendix A: Evaluation of Applicability of NQA-1 to SFR Metallic Fuel Historical Data Qualification Process}

\begin{tabular}{|c|c|}
\hline NQA-1-2008/9 Requirements & Applicability \\
\hline $\begin{array}{l}\text { organization shall be clearly defined and documented. } \\
\text { The external interfaces between organizations and the internal interfaces between organizational units, and changes thereto, shall } \\
\text { be documented. }\end{array}$ & \\
\hline Req. 2 Quality Assurance Program & \\
\hline $\begin{array}{l}\text { Req. 2, } 100 \text { GENERAL } \\
\text { (a) A documented quality assurance program shall be planned, implemented, and maintained in accordance with this Part (Part I), or } \\
\text { portions thereof. The program shall identify the activities and items to which it applies. The program shall provide control over } \\
\text { activities affecting quality to an extent consistent with their importance. The program shall include monitoring activities against } \\
\text { acceptance criteria in a manner sufficient to provide assurance that the activities affecting quality are performed satisfactorily. The } \\
\text { program shall be established at the earliest time consistent with the schedule for accomplishing the activities. } \\
\text { The program shall provide for the planning and accomplishment of activities affecting quality under suitably controlled conditions. } \\
\text { Controlled conditions include the use of appropriate equipment, suitable environmental conditions for accomplishing the activity, and } \\
\text { assurance that prerequisites for the given activity have been satisfied. The program shall provide for any special controls, processes, } \\
\text { test equipment, tools, and skills to attain the required quality of activities and items and for verification of that quality. The } \\
\text { organization shall establish and implement processes to detect and correct quality problems. } \\
\text { (b) The program shall provide for indoctrination, training, and qualification as necessary of personnel performing or managing } \\
\text { activities affecting quality to ensure that suitable proficiency is achieved and maintained. } \\
\text { (c) Management shall regularly assess the adequacy and effective implementation of the quality assurance program. }\end{array}$ & $\begin{array}{l}\text { Applicable and implemented in } \\
\text { accordance with the Argonne } \\
\text { QAPP. }\end{array}$ \\
\hline $\begin{array}{l}\text { Req. 2, } 200 \text { INDOCTRINATION AND TRAINING } \\
\text { Indoctrination and training shall be commensurate with scope, complexity, importance of the activities, and the education, } \\
\text { experience, and proficiency of the person. }\end{array}$ & $\begin{array}{l}\text { Applicable and implemented in } \\
\text { accordance with the Argonne } \\
\text { QAPP. }\end{array}$ \\
\hline $\begin{array}{l}\text { Req. 2, } 201 \text { Indoctrination } \\
\text { Personnel performing or managing activities affecting quality shall receive indoctrination in their job responsibilities and authority that } \\
\text { includes general criteria, technical objectives, requirements of applicable codes and standards, regulatory commitments, company } \\
\text { procedures, and quality assurance program requirements. }\end{array}$ & $\begin{array}{l}\text { Applicable and implemented in } \\
\text { accordance with the Argonne } \\
\text { QAPP. }\end{array}$ \\
\hline $\begin{array}{l}\text { Req. 2, } 202 \text { Training } \\
\text { The need for a formal training program for personnel performing or managing activities affecting quality shall be determined. Training } \\
\text { shall be provided, if needed, to achieve initial proficiency, maintain proficiency, and adapt to changes in technology, methods, or job } \\
\text { responsibilities. On-the-job training shall be used if direct hands-on applications or experience is needed to achieve and maintain } \\
\text { proficiency. }\end{array}$ & $\begin{array}{l}\text { Applicable and implemented in } \\
\text { accordance with the Argonne } \\
\text { QAPP. }\end{array}$ \\
\hline
\end{tabular}




\section{Appendix A: Evaluation of Applicability of NQA-1 to SFR Metallic Fuel Historical Data Qualification Process}

\begin{tabular}{|c|c|}
\hline NQA-1-2008/9 Requirements & Applicability \\
\hline $\begin{array}{l}\text { Req. 2, } 300 \text { QUALIFICATION REQUIREMENTS } \\
\text { The responsible organization shall designate those activities that require qualification of personnel and the minimum requirements } \\
\text { for such personnel. The responsible organization shall establish written procedures for the qualification of personnel, and for the } \\
\text { assurance that only those personnel who meet the requirements are permitted to perform these activities. } \\
\text { Specific qualification requirements for personnel performing nondestructive examination, inspection and tests to verify quality, and } \\
\text { auditing are specified in paras. } 301 \text { through } 304 \text { of this Requirement. }\end{array}$ & $\begin{array}{l}\text { Applicable and implemented in } \\
\text { accordance with the Argonne } \\
\text { QAPP. }\end{array}$ \\
\hline $\begin{array}{l}301 \text { Nondestructive Examination (NDE) } \\
\text { This paragraph specifies requirements for the qualification of personnel who perform radiographic (RT), magnetic particle (MP), } \\
\text { ultrasonic (UT), liquid penetrant (PT), electromagnetic (ET), neutron radiographic (NR), leak testing (LT), acoustic emission (AE), } \\
\text { and visual testing (VT) to verify conformance to the specified requirements. The American Society of Nondestructive Testing (ASNT) } \\
\text { Recommended Practices or Standards provide acceptable qualification requirements for NDE personnel. Applicable Codes and } \\
\text { Standards or design criteria controlling the qualification of NDE personnel shall be utilized to establish the applicable ASNT } \\
\text { qualification requirement and edition or to specify an equivalent alternative requirement. }\end{array}$ & Not Applicable \\
\hline $\begin{array}{l}302 \text { Inspection and Test } \\
\text { The initial capabilities of a candidate shall be determined by an evaluation of the candidate's education, experience, training, or } \\
\text { capability demonstration. Reevaluation shall be by evidence of continued satisfactory performance or redetermination of capability in } \\
\text { accordance with the requirements of section } 200 \text { of this Requirement. If during this evaluation or at any other time, it is determined } \\
\text { by the responsible organization that the capabilities of an individual are not in accordance with the qualification requirements } \\
\text { specified for the job, that person shall be removed from that activity until such time as the required capability has been } \\
\text { demonstrated. Any person who has not performed inspection or testing activities in the qualified area for a period of } 1 \text { yr. shall be } \\
\text { reevaluated. }\end{array}$ & $\begin{array}{l}\text { Applicable to personnel engaged in } \\
\text { in software review and } \\
\text { implemented in accordance with } \\
\text { the Argonne QAPP. }\end{array}$ \\
\hline $\begin{array}{l}303 \text { Lead Auditor } \\
\text { The Lead Auditor organizes and directs audits, reports audit findings, and evaluates corrective action. An individual shall meet the } \\
\text { requirements of paras. } 303.1 \text { through } 303.6 \text { of this Requirement prior to being designated a Lead Auditor. }\end{array}$ & $\begin{array}{l}\text { Applicable and implemented in } \\
\text { accordance with the Argonne } \\
\text { QAPP. }\end{array}$ \\
\hline $\begin{array}{l}\text { 303.1 Communication Skills. } \\
\text { The prospective Lead Auditor shall be capable of communicating effectively, both in writing and orally. These skills shall be attested } \\
\text { to in writing by the Lead Auditor's employer. }\end{array}$ & $\begin{array}{l}\text { Applicable and implemented in } \\
\text { accordance with the Argonne } \\
\text { QAPP. }\end{array}$ \\
\hline
\end{tabular}




\section{Appendix A: Evaluation of Applicability of NQA-1 to SFR Metallic Fuel Historical Data Qualification Process}

\begin{tabular}{|c|c|}
\hline NQA-1-2008/9 Requirements & Applicability \\
\hline $\begin{array}{l}\text { 303.2 Training. } \\
\text { Prospective Lead Auditors shall receive training to the extent necessary to assure auditing competence including } \\
\text { (a) knowledge and understanding of this Standard and other nuclear-related codes, standards, regulations, and regulatory guides, as } \\
\text { applicable } \\
\text { (b) general structure of quality assurance programs as a whole and applicable elements as defined in this Standard } \\
\text { (c) auditing techniques of examining, questioning, evaluating, and reporting; methods of identifying and following up on corrective } \\
\text { action items; and closing out audit findings } \\
\text { (d) planning audits of activities affecting quality } \\
\text { (e) on-the-job training to include applicable elements of the audit program }\end{array}$ & $\begin{array}{l}\text { Applicable and implemented in } \\
\text { accordance with the Argonne } \\
\text { QAPP. }\end{array}$ \\
\hline $\begin{array}{l}\text { 303.3 Audit Participation. } \\
\text { Prospective Lead Auditors shall participate in a minimum of five quality assurance audits within a period of time not to exceed } 3 \text { yr. } \\
\text { prior to the date of qualification, one audit of which shall be a nuclear quality assurance audit within the year prior to qualification. } \\
\text { Participation in independent assessments including team assessment activities such as operations readiness reviews and regulatory } \\
\text { inspections/surveys may be used to satisfy up to four of the five required quality assurance audits, provided that the activities can } \\
\text { demonstrate the following: } \\
\text { (a) independence from the functional areas being assessed } \\
\text { (b) planning that establishes the scope of the activities and associated evaluation criteria } \\
\text { (c) performance by technically qualified and experienced personnel } \\
\text { (d) results that are documented and reported to management } \\
\text { (e) appropriate corrective action initiated and tracked to resolution } \\
\text { Such participation shall be subject to review and acceptance by the organization responsible for quality assurance audits and/or the } \\
\text { certifying authority prior to their use for qualification. }\end{array}$ & $\begin{array}{l}\text { Applicable and implemented in } \\
\text { accordance with the Argonne } \\
\text { QAPP. }\end{array}$ \\
\hline $\begin{array}{l}\text { 303.4 Examination. } \\
\text { Prospective Lead Auditors shall pass an examination that shall evaluate comprehension of and ability to apply the body of } \\
\text { knowledge identified above. The examination may be oral, written, practical, or any combination thereof. }\end{array}$ & $\begin{array}{l}\text { Applicable and implemented in } \\
\text { accordance with the Argonne } \\
\text { QAPP. }\end{array}$ \\
\hline
\end{tabular}




\section{Appendix A: Evaluation of Applicability of NQA-1 to SFR Metallic Fuel Historical Data Qualification Process}

\begin{tabular}{|c|c|}
\hline NQA-1-2008/9 Requirements & Applicability \\
\hline $\begin{array}{l}\text { 303.5 Maintenance of Proficiency. } \\
\text { Lead Auditors shall maintain their proficiency through one or more of the following: } \\
\text { (a) regular and active participation in the audit process } \\
\text { (b) review and study of codes, standards, procedures, instructions, and other documents related to quality assurance program and } \\
\text { program auditing } \\
\text { (c) participation in training program(s) } \\
\text { Based on annual assessment, management may extend the qualification, require retraining, or require requalification. }\end{array}$ & $\begin{array}{l}\text { Applicable and implemented in } \\
\text { accordance with the Argonne } \\
\text { QAPP. }\end{array}$ \\
\hline $\begin{array}{l}\text { 303.6 Requalification. } \\
\text { Lead Auditors who fail to maintain their proficiency for a period of } 2 \text { yr. or more shall require requalification. Requalification shall } \\
\text { include retraining in accordance with the requirements of para. } 303.2 \text { of this Requirement, reexamination in accordance with para. } \\
\text { 303.4 of this Requirement, and participation as an Auditor in at least one nuclear quality assurance audit. }\end{array}$ & $\begin{array}{l}\text { Applicable and implemented in } \\
\text { accordance with the Argonne } \\
\text { QAPP. }\end{array}$ \\
\hline $\begin{array}{l}304 \text { Auditors } \\
\text { Auditors are participants in an audit. Auditors shall have, or be given, appropriate training or orientation to develop their competence } \\
\text { for performing audits. Competence of personnel for performance of the various auditing functions shall be developed by one or more } \\
\text { of the following methods: } \\
\text { (a) orientation to provide a working knowledge and understanding of this Standard and the auditing organization's procedures for } \\
\text { implementing audits and reporting results. } \\
\text { (b) general and specialized training in audit performance where the general training shall include fundamentals, objectives, } \\
\text { characteristics, organization, performance, and results of quality auditing and the specialized training shall include methods of } \\
\text { examining, questioning, evaluating, and documenting specific audit items and methods of closing out audit findings. } \\
\text { (c) on-the-job training, guidance, and counseling under the direct supervision of a Lead Auditor. Such training shall include planning, } \\
\text { performing, reporting, and follow-up action involved in conducting audits. }\end{array}$ & $\begin{array}{l}\text { Applicable and implemented in } \\
\text { accordance with the Argonne } \\
\text { QAPP. }\end{array}$ \\
\hline $\begin{array}{l}305 \text { Technical Specialists } \\
\text { The responsible auditing organization shall establish the qualifications and requirements for use of technical specialists to } \\
\text { accomplish the auditing of quality assurance programs. }\end{array}$ & $\begin{array}{l}\text { Applicable and implemented in } \\
\text { accordance with the Argonne } \\
\text { QAPP. }\end{array}$ \\
\hline
\end{tabular}




\section{Appendix A: Evaluation of Applicability of NQA-1 to SFR Metallic Fuel Historical Data Qualification Process}

\begin{tabular}{|c|c|}
\hline NQA-1-2008/9 Requirements & Applicability \\
\hline $\begin{array}{l}400 \text { RECORDS OF QUALIFICATION } \\
\text { (a) The qualification of inspection, test, and Lead Auditor personnel shall be certified in writing and include the following information: } \\
\text { (1) employer's name } \\
\text { (2) identification of person being certified } \\
\text { (3) activities certified to perform } \\
\text { (4) basis of qualification } \\
\text { (a) education, experience, indoctrination, and training } \\
\text { (b) test results, where applicable } \\
\text { (c) capability demonstration results } \\
\text { (5) results of periodic evaluation } \\
\text { (6) results of physical examinations, when required } \\
\text { (7) signature of employer's designated representative who is responsible for such certification } \\
\text { (8) date of certification or recertification and certification expiration } \\
\text { (b) The responsible organization shall identify any special physical characteristics needed in the performance of each activity, } \\
\text { including the need for initial and subsequent physical examination. } \\
\text { The employer may delegate qualification examination activities to an independent certifying agency, but shall retain responsibility for } \\
\text { conformance of the examination and its administration. Integrity of the examination shall be maintained by the employer or certifying } \\
\text { agency through appropriate confidentiality of files and, where applicable, proctoring of examinations. Copies of the objective } \\
\text { evidence regarding the type(s) and content of the examination(s) shall be retained by the employer in accordance with the } \\
\text { requirements of Section } 500 \text { of this Requirement. }\end{array}$ & $\begin{array}{l}\text { Applicable and implemented in } \\
\text { accordance with the Argonne } \\
\text { QAPP. }\end{array}$ \\
\hline $\begin{array}{l}\text { Req. 2, } 500 \text { RECORDS } \\
\text { Records of indoctrination and training shall include one or more of the following: } \\
\text { (a) attendance sheets } \\
\text { (b) training logs } \\
\text { (c) personnel training records } \\
\text { The employer shall establish and maintain records for indoctrination and training, Auditor and Lead Auditor qualification and } \\
\text { requalification, and inspection and test personnel qualification and requalification. }\end{array}$ & $\begin{array}{l}\text { Applicable and implemented in } \\
\text { accordance with the Argonne } \\
\text { QAPP. }\end{array}$ \\
\hline
\end{tabular}




\section{Appendix A: Evaluation of Applicability of NQA-1 to SFR Metallic Fuel Historical Data Qualification Process}

\begin{tabular}{|c|c|}
\hline NQA-1-2008/9 Requirements & Applicability \\
\hline \multicolumn{2}{|l|}{ Req. 3 Design Control } \\
\hline $\begin{array}{l}\text { Req. 3, } 100 \text { GENERAL } \\
\text { The design shall be defined, controlled, and verified. Design inputs shall be specified on a timely basis and translated into design } \\
\text { documents. Design interfaces shall be identified and controlled. Design adequacy shall be verified by individuals other than those } \\
\text { who designed the item or computer program. Design changes shall be governed by control measures commensurate with those } \\
\text { applied to the original design. }\end{array}$ & $\begin{array}{l}\text { Applicable however software will be } \\
\text { managed in accordance with } \\
\text { section } 800 \text { Software Design }\end{array}$ \\
\hline $\begin{array}{l}\text { Req. 3, } 200 \text { DESIGN INPUT } \\
\text { Applicable design inputs shall be identified and documented, and their selection reviewed and approved. The design input shall be } \\
\text { specified to the level of detail necessary to permit the design activities to be carried out in a correct manner and to provide a } \\
\text { consistent basis for making design decisions, accomplishing design verification measures, and evaluating design changes. }\end{array}$ & $\begin{array}{l}\text { Applicable however software will be } \\
\text { managed in accordance with } \\
\text { section } 800 \text { Software Design } \\
\text { Control. }\end{array}$ \\
\hline $\begin{array}{l}300 \text { DESIGN PROCESS } \\
\text { (a) The responsible design organization shall prescribe and document the design activities to the level of detail necessary to permit } \\
\text { the design process to be carried out in a correct manner, and to permit verification that the design meets requirements. Design } \\
\text { documents shall support facility design, construction, and operation. Appropriate quality standards shall be identified and } \\
\text { documented, and their selection reviewed and approved. }\end{array}$ & $\begin{array}{l}\text { Applicable however software will be } \\
\text { managed in accordance with } \\
\text { section } 800 \text { Software Design } \\
\text { Control. }\end{array}$ \\
\hline $\begin{array}{l}\text { (b) The design methods, materials, parts, equipment, and processes that are essential to the function of the items shall be selected } \\
\text { and reviewed for suitability of application. Applicable information derived from experience, as set forth in reports or other } \\
\text { documentation, shall be made available to cognizant design personnel. }\end{array}$ & \\
\hline \multicolumn{2}{|l|}{ (c) The final design shall } \\
\hline \multicolumn{2}{|l|}{ (1) be relatable to the design input by documentation in sufficient detail to permit design verification. } \\
\hline \multicolumn{2}{|l|}{ (2) specify required inspections and tests and include or reference appropriate acceptance criteria. } \\
\hline \multicolumn{2}{|l|}{$\begin{array}{l}\text { (3) identify assemblies and/or components that are part of the item being designed. When such an assembly or component part is } \\
\text { a commercial grade item, the critical characteristics of the item to be verified for acceptance and the acceptance criteria for those } \\
\text { characteristics shall meet the requirements of Part II, Subpart 2.14, Quality Assurance Requirements for Commercial Grade Items } \\
\text { and Services. }\end{array}$} \\
\hline $\begin{array}{l}\text { Critical characteristics to be verified are those that provide reasonable assurance that the item will perform its intended safety } \\
\text { function. If a commercial grade item, prior to its installation, is modified or selected by special inspection and/or testing to } \\
\text { requirements that are more restrictive than the Supplier's published product description, the component part shall be represented as } \\
\text { different from the commercial grade item in a manner traceable to a documented definition of the difference. }\end{array}$ & \\
\hline
\end{tabular}




\section{Appendix A: Evaluation of Applicability of NQA-1 to SFR Metallic Fuel Historical Data Qualification Process}

\begin{tabular}{|c|c|}
\hline NQA-1-2008/9 Requirements & Applicability \\
\hline $\begin{array}{l}400 \text { DESIGN ANALYSES } \\
\text { Design analyses shall be sufficiently detailed such that a person technically qualified in the subject can review and understand the } \\
\text { analyses and verify the adequacy of the results without recourse to the originator. }\end{array}$ & $\begin{array}{l}\text { Applicable however software will be } \\
\text { managed in accordance with } \\
\text { section } 800 \text { Software Design } \\
\text { Control. }\end{array}$ \\
\hline $\begin{array}{l}401 \text { Use of Computer Programs } \\
\text { To the extent required in paras. } 401(\mathrm{a}) \text { and (b) of this Requirement, computer program acceptability shall be preverified or the results } \\
\text { verified with the design analysis for each application. Preverified computer programs shall be controlled in accordance with the } \\
\text { requirements of this Standard. } \\
\text { (a) The computer program, shall be verified to show that it produces correct solutions for the encoded mathematical model within } \\
\text { defined limits for each parameter employed. } \\
\text { (b) The encoded mathematical model shall be shown to produce a valid solution to the physical problem associated with the } \\
\text { particular application. }\end{array}$ & Applicable \\
\hline $\begin{array}{l}402 \text { Documentation of Design Analyses } \\
\text { Documentation of design analyses shall include the following: } \\
\text { (a) the objective of the analyses } \\
\text { (b) design inputs and their sources } \\
\text { (c) results of literature searches or other applicable background data } \\
\text { (d) assumptions and indication of those assumptions that must be verified as the design proceeds } \\
\text { (e) identification of any computer calculation, including identification of the computer type, computer program name, and revision, } \\
\text { inputs, outputs, evidence of or reference to computer program verification, and the bases (of reference thereto) supporting } \\
\text { application of the computer program to the specific physical problem } \\
\text { (f) review and approval }\end{array}$ & Applicable. \\
\hline
\end{tabular}




\section{Appendix A: Evaluation of Applicability of NQA-1 to SFR Metallic Fuel Historical Data Qualification Process}

\begin{tabular}{|c|c|}
\hline NQA-1-2008/9 Requirements & Applicability \\
\hline $\begin{array}{l}500 \text { DESIGN VERIFICATION } \\
\text { (a) The responsible design organization shall identify and document the particular design verification method(s) used. The results of } \\
\text { design verification shall be documented with the identification of the verifier clearly indicated. Design verification shall be performed } \\
\text { by any competent individual(s) or group(s) other than those who performed the original design but who may be from the same } \\
\text { organization. This verification may be performed by the originator's supervisor, provided } \\
\text { (1) the supervisor did not specify a singular design approach or rule out certain design considerations and did not establish the } \\
\text { design inputs used in the design; or } \\
\text { (2) the supervisor is the only individual in the organization competent to perform the verification. } \\
\text { Cursory supervisory reviews do not satisfy the intent of this Standard. } \\
\text { (b) Design verification shall be performed prior to releasing the design for procurement, manufacture, construction, or use by another } \\
\text { design organization, except where this timing cannot be met, such as when insufficient data exist. In those cases, the unverified } \\
\text { portion of the design shall be identified and controlled. In all cases the design verification shall be completed prior to relying upon the } \\
\text { component, system, structure, or computer program to perform its function. } \\
\text { (c) If the design is modified to resolve verification findings, the modified design shall be verified prior to release or use. } \\
\text { (d) Extent of Design Verification. The extent of the design verification shall be a function of the importance to safety, the complexity } \\
\text { of the design, the degree of standardization, the state of the art, and the similarity with previously proved designs. Where the design } \\
\text { has been subjected to a verification process in accordance with this Part (Part I), the verification process need not be duplicated for } \\
\text { identical designs. However, the applicability of standardized or previously proven designs, with respect to meeting pertinent design } \\
\text { inputs, shall be verified for each application. Known problems affecting the standard or previously proved designs and their effects } \\
\text { on other features shall be considered. The original design and associated verification documentation shall be referenced in records } \\
\text { of subsequent application of the design. }\end{array}$ & $\begin{array}{l}\text { Applicable however software will be } \\
\text { managed in accordance with } \\
\text { section } 800 \text { Software Design } \\
\text { Control. }\end{array}$ \\
\hline $\begin{array}{l}501 \text { Methods } \\
\text { Acceptable verification methods include, but are not limited to, any one or a combination of the following: } \\
\text { (a) design reviews } \\
\text { (b) alternate calculations } \\
\text { (c) qualification testing }\end{array}$ & Applicable \\
\hline $\begin{array}{l}501.1 \text { Design Reviews. } \\
\text { Design reviews shall provide assurance that the final design is correct and satisfactory by addressing, where applicable, paras. } \\
501.1 \text { (a) through (g) of this Requirement. } \\
\text { (a) Were the design inputs correctly selected? } \\
\text { (b) Are assumptions necessary to perform the design activity adequately described and reasonable? Where necessary, are the } \\
\text { assumptions identified for subsequent reverifications when the detailed design activities are completed? }\end{array}$ & Applicable \\
\hline
\end{tabular}




\section{Appendix A: Evaluation of Applicability of NQA-1 to SFR Metallic Fuel Historical Data Qualification Process}

\begin{tabular}{|c|c|}
\hline NQA-1-2008/9 Requirements & Applicability \\
\hline $\begin{array}{l}\text { (c) Were appropriate design methods and computer programs used? } \\
\text { (d) Were the design inputs correctly incorporated into the design? } \\
\text { (e) Is the design output reasonable compared to design inputs? } \\
\text { (f) Are the necessary design inputs for interfacing organizations specified in the design documents or in supporting procedures or } \\
\text { instructions? } \\
\text { (g) Have suitable materials, parts, processes, and inspection and testing criteria been specified? }\end{array}$ & \\
\hline $\begin{array}{l}\text { 501.2 Alternate Calculations. } \\
\text { Alternate calculations shall use alternate methods to verify correctness of the original calculations or analyses. The appropriateness } \\
\text { of assumptions; input data used; and the computer program, its associated computer hardware and system software, or other } \\
\text { calculation method used shall also be reviewed. }\end{array}$ & Applicable \\
\hline $\begin{array}{l}501.3 \text { Qualification Tests. } \\
\text { Testing shall demonstrate adequacy of performance under conditions that simulate the most adverse design conditions. Operating } \\
\text { modes and environmental conditions shall be considered in determining the most adverse conditions. Where the test is intended to } \\
\text { verify only specific design features, the other features of the design shall be verified by other means. When tests are being } \\
\text { performed on models or mockups, scaling laws shall be established and verified. The results of model test work shall be subject to } \\
\text { error analysis, where applicable, prior to use in the final design. }\end{array}$ & Applicable \\
\hline $\begin{array}{l}600 \text { CHANGE CONTROL } \\
\text { (a) Changes to design inputs, final designs, field changes, and temporary and permanent modifications to operating facilities shall be } \\
\text { justified and subject to design control measures commensurate with those applied to the original design. These measures shall } \\
\text { include evaluation of effects of those changes on the overall design and on any analysis upon which the design is based. The } \\
\text { evaluation shall include facility configurations that occur during operation, maintenance, test, surveillance, and inspection activities. } \\
\text { Changes shall be approved by the same affected groups or organizations that reviewed and approved the original design } \\
\text { documents. When the organization originally responsible for review and approval of the original design documents is no longer } \\
\text { responsible, the owner or his designee shall have responsibility or designate a new responsible organization. The design } \\
\text { organization approving the change shall have demonstrated competence in the specific design area of interest and have an } \\
\text { adequate understanding of the requirements and intent of the original design. } \\
\text { (b) When a design change is approved other than by revision to the affected design documents, measures shall be established to } \\
\text { incorporate the change into these documents, where such incorporation is appropriate. } \\
\text { (c) Where a significant design change is necessary because of an incorrect design, the design process and verification procedure } \\
\text { shall be reviewed and modified as necessary. }\end{array}$ & $\begin{array}{l}\text { Applicable however software will be } \\
\text { managed in accordance with } \\
\text { section } 800 \text { Software Design } \\
\text { Control }\end{array}$ \\
\hline
\end{tabular}




\section{Appendix A: Evaluation of Applicability of NQA-1 to SFR Metallic Fuel Historical Data Qualification Process}

\begin{tabular}{|c|c|}
\hline NQA-1-2008/9 Requirements & Applicability \\
\hline $\begin{array}{l}601 \text { Configuration Management of Operating Facilities } \\
\text { Procedures implementing configuration management requirements shall be established and documented at the earliest practical } \\
\text { time prior to facility operation. These procedures shall include the responsibilities and authority of the organizations whose functions } \\
\text { affect the configuration of the facility including activities such as operations, design, maintenance, construction, licensing, and } \\
\text { procurement. }\end{array}$ & Not Applicable \\
\hline $\begin{array}{l}\text { 601.1 Configuration management requirements shall include measures to ensure changes that may affect the approved } \\
\text { configuration are recognized and processed. }\end{array}$ & Not Applicable \\
\hline $\begin{array}{l}\text { 601.2 The configuration shall be established and approved at the earliest practical time prior to initial operation of the facility, and } \\
\text { maintained for the life of the facility. }\end{array}$ & Not Applicable \\
\hline $\begin{array}{l}\text { 601.3 The configuration shall include, as applicable, characteristics derived from regulatory requirements and commitments, } \\
\text { calculations and analyses, design inputs, installation and test requirements, supplier manuals and instructions, operating and } \\
\text { maintenance requirements, and other applicable sources. }\end{array}$ & Not Applicable \\
\hline 601.4 Interface controls shall include the integration of activities of organizations that can affect the approved configuration. & Not Applicable \\
\hline 601.5 Documentation shall identify the design bases and the approved configuration for the approved modes of operation. & Not Applicable \\
\hline $\begin{array}{l}\text { 601.6 Measures shall be established and implemented to ensure that proposed changes to the configuration are evaluated for their } \\
\text { conformance to the design bases. }\end{array}$ & Not Applicable \\
\hline $\begin{array}{l}\text { 601.7 The implementation sequence for approved configuration changes shall be reviewed to determine that the configuration } \\
\text { conforms to the design bases. }\end{array}$ & Not Applicable \\
\hline 601.8 Approval by the design authority shall be required prior to implementation of a change to the design bases. & Not Applicable \\
\hline $\begin{array}{l}\text { 601.9 The configuration of the facility shall be documented in drawings, specifications, procedures, and other documents that reflect } \\
\text { the operational status of the facility. The process used to control the current revision and issuance of these documents shall take into } \\
\text { account the use of the document and the need for revision in support of operation. }\end{array}$ & Not Applicable \\
\hline $\begin{array}{l}700 \text { INTERFACE CONTROL } \\
\text { Interface controls shall include assignment of responsibility and establishment of procedures among participating design } \\
\text { organizations for review, approval, release, distribution, and revision of documents involving design interfaces. }\end{array}$ & Not Applicable \\
\hline
\end{tabular}




\section{Appendix A: Evaluation of Applicability of NQA-1 to SFR Metallic Fuel Historical Data Qualification Process}

\begin{tabular}{|c|c|}
\hline NQA-1-2008/9 Requirements & Applicability \\
\hline $\begin{array}{l}\text { Design information transmitted across interfaces shall identify the status of the design information or document provided, and identify } \\
\text { incomplete items that require further evaluation, review, or approval. Where it is necessary to initially transmit design information } \\
\text { orally or by other informal means, the transmittal shall be confirmed promptly by a controlled document. }\end{array}$ & \\
\hline $\begin{array}{l}800 \text { SOFTWARE DESIGN CONTROL } \\
\text { The requirements of Section } 800 \text { apply to computer software design control and shall be used instead of section } 200 \text {, Design Input; } \\
\text { section } 300 \text {, Design Process; section 500, Design Verification; and section } 600 \text {, Change Control. Part 11, Subpart } 2.7 \text {, Quality } \\
\text { Assurance Requirements for Computer Software for Nuclear Facility Applications, provides work practice requirements to implement } \\
\text { the requirements of this paragraph. }\end{array}$ & Applicable \\
\hline $\begin{array}{l}801 \text { Software Design Process } \\
\text { The software design process shall be documented, approved by the responsible design organization, and controlled. This process } \\
\text { shall include the activities described in paras. } 801.1 \text { through } 801.5 \text { of this Requirement. }\end{array}$ & Applicable \\
\hline $\begin{array}{l}\text { 801.1 Identification of Software Design Requirements. Software design requirements shall be identified and documented and } \\
\text { their selection reviewed and approved. The software requirements shall identify the operating system, function, interfaces, } \\
\text { performance requirements, installation considerations, design inputs, and any design constraints of the computer program. }\end{array}$ & Applicable \\
\hline $\begin{array}{l}\text { 801.2 Software Design. The software design shall be documented and shall define the computational sequence necessary to meet } \\
\text { the software requirements. The documentation shall include, as applicable, numerical methods, mathematical models, physical } \\
\text { models, control flow, control logic, data flow, process flow, data structures, process structures, and the applicable relationships } \\
\text { between data structures and process structures. This documentation may be combined with the documentation of the software } \\
\text { design requirements, or the computer program listings resulting from implementation of the software design. }\end{array}$ & Applicable \\
\hline $\begin{array}{l}801.3 \text { Implementation of the Software Design. The software design shall be translated into computer program using the } \\
\text { programming organization's or design organization's programming standards and conventions. }\end{array}$ & Applicable \\
\hline $\begin{array}{l}\text { 801.4 Software Design Verification. Software design verification shall be performed by a competent individual (or group(s)) other } \\
\text { than those who developed and documented the original design, but who may be from the same organization. This verification may } \\
\text { be performed by the originator's supervisor, provided } \\
\text { (a) the supervisor did not specify a singular design approach or rule out certain design considerations and did not establish the } \\
\text { design inputs used in the design, or } \\
\text { (b) the supervisor is the only individual in the organization competent to perform the verification. } \\
\text { Cursory supervisory reviews do not satisfy the intent of this Standard. } \\
\text { The results of verification shall be documented with the identification of the verifier indicated. Software verification methods shall } \\
\text { include any one or a combination of design reviews, alternate calculations, and tests performed during computer program } \\
\text { development. The extent of verification and the methods chosen are a function of the complexity of the software, the degree of }\end{array}$ & Applicable \\
\hline
\end{tabular}




\section{Appendix A: Evaluation of Applicability of NQA-1 to SFR Metallic Fuel Historical Data Qualification Process}

\begin{tabular}{|c|c|}
\hline NQA-1-2008/9 Requirements & Applicability \\
\hline standardization, the similarity with previously proved software, and the importance to safety. & \\
\hline 801.5 Computer Program Testing. Computer program testing shall be performed and shall be in accordance with Requirement 11 . & Applicable \\
\hline $\begin{array}{l}802 \text { Software Configuration Management. Software configuration management includes, but is not limited to configuration } \\
\text { identification, change control, and status control. Configuration items shall be maintained under configuration management until the } \\
\text { software is retired. }\end{array}$ & Applicable \\
\hline $\begin{array}{l}\text { 802.1 Configuration Identification. A software baseline shall be established at the completion of each activity of the software } \\
\text { design process. Approved changes created subsequent to a baseline shall be added to the baseline. A baseline shall define the } \\
\text { most recently approved software configuration. A labeling system for configuration items shall be implemented that } \\
\text { (a) uniquely identifies each configuration item } \\
\text { (b) identifies changes to configuration items by revision } \\
\text { (c) provides the ability to uniquely identify each configuration of the revised software available for use }\end{array}$ & Applicable \\
\hline $\begin{array}{l}\text { 802.2 Configuration Change Control. Changes to software shall be formally documented. The documentation shall include } \\
\text { (a) a description of the change } \\
\text { (b) the rationale for the change } \\
\text { (c) the identification of affected software baselines } \\
\text { The change shall be formally evaluated and approved by the organization responsible for the original design, unless an alternate } \\
\text { organization has been given the authority to approve the changes. Only authorized changes shall be made to software baselines. } \\
\text { Appropriate verification activities shall be performed for the change. The change shall be appropriately reflected in documentation, } \\
\text { and traceability of the change to the software design requirement shall be maintained. } \\
\text { Appropriate acceptance testing shall be performed for the change. }\end{array}$ & Applicable \\
\hline $\begin{array}{l}\text { 802.3 Configuration Status Control. The status of configuration items resulting from software design shall be maintained current. } \\
\text { Configuration item changes shall be controlled until they are incorporated into the approved product baseline. The controls shall } \\
\text { include a process for maintaining the status of changes that are proposed and approved, but not implemented. The controls shall } \\
\text { also provide for notification of this information to affected organizations. }\end{array}$ & Applicable \\
\hline $\begin{array}{l}900 \text { DOCUMENTATION AND RECORDS } \\
\text { Design documentation and records shall include not only final design documents, such as drawings and specifications, and revisions } \\
\text { to those documents, but also documentation that identifies the important steps in the design process, including sources of design } \\
\text { inputs that support the final design. }\end{array}$ & Applicable \\
\hline
\end{tabular}




\section{Appendix A: Evaluation of Applicability of NQA-1 to SFR Metallic Fuel Historical Data Qualification Process}

\begin{tabular}{|c|c|}
\hline NQA-1-2008/9 Requirements & Applicability \\
\hline Req. 4 Procurement Document Control & \\
\hline $\begin{array}{l}100 \text { GENERAL } \\
\text { Applicable design bases and other requirements necessary to assure adequate quality shall be included or referenced in documents } \\
\text { for procurement of items and services. To the extent necessary, procurement documents shall require Suppliers to have a quality } \\
\text { assurance program consistent with the applicable requirements of this Standard. }\end{array}$ & Applicable \\
\hline $\begin{array}{l}200 \text { CONTENT OF THE PROCUREMENT DOCUMENTS } \\
\text { Procurement documents issued at all tiers of procurement shall include provisions for the following, as deemed necessary by the } \\
\text { Purchaser. }\end{array}$ & Applicable \\
\hline $\begin{array}{l}201 \text { Scope of Work } \\
\text { Procurement documents shall include a statement of the scope of the work to be performed by the Supplier. }\end{array}$ & Applicable \\
\hline $\begin{array}{l}202 \text { Technical Requirements } \\
\text { Technical requirements shall be specified in the procurement documents. These requirements shall be specified, as appropriate by } \\
\text { reference to specific drawings, specifications, codes, standards, regulations, procedures, or instructions, including revisions thereto } \\
\text { that describe the items or services to be furnished. The procurement documents shall identify appropriate test, inspection, and } \\
\text { acceptance criteria for determining acceptability of the item or service. }\end{array}$ & Applicable \\
\hline $\begin{array}{l}203 \text { Quality Assurance Program Requirements } \\
\text { Quality assurance program requirements shall be specified in the procurement documents. These requirements shall be consistent } \\
\text { with importance and/or complexity of the item or service being procured. The procurement documents shall require the Supplier to } \\
\text { incorporate appropriate quality assurance program requirements in sub tier procurement documents. }\end{array}$ & Applicable \\
\hline $\begin{array}{l}204 \text { Right of Access } \\
\text { The procurement documents shall provide for access to the Supplier's and sub tier Supplier's facilities and records for surveillance, } \\
\text { inspection, or audit by the Purchaser, its designated representative, and others authorized by the Purchaser. }\end{array}$ & Applicable \\
\hline $\begin{array}{l}205 \text { Documentation Requirements } \\
\text { The procurement documents shall identify the documentation required to be submitted for information, review, or approval by the } \\
\text { Purchaser. The time of submittal shall also be established. When the Purchaser requires the Supplier to maintain specific records, } \\
\text { the retention times and disposition requirements shall be prescribed. }\end{array}$ & Applicable \\
\hline
\end{tabular}




\section{Appendix A: Evaluation of Applicability of NQA-1 to SFR Metallic Fuel Historical Data Qualification Process}

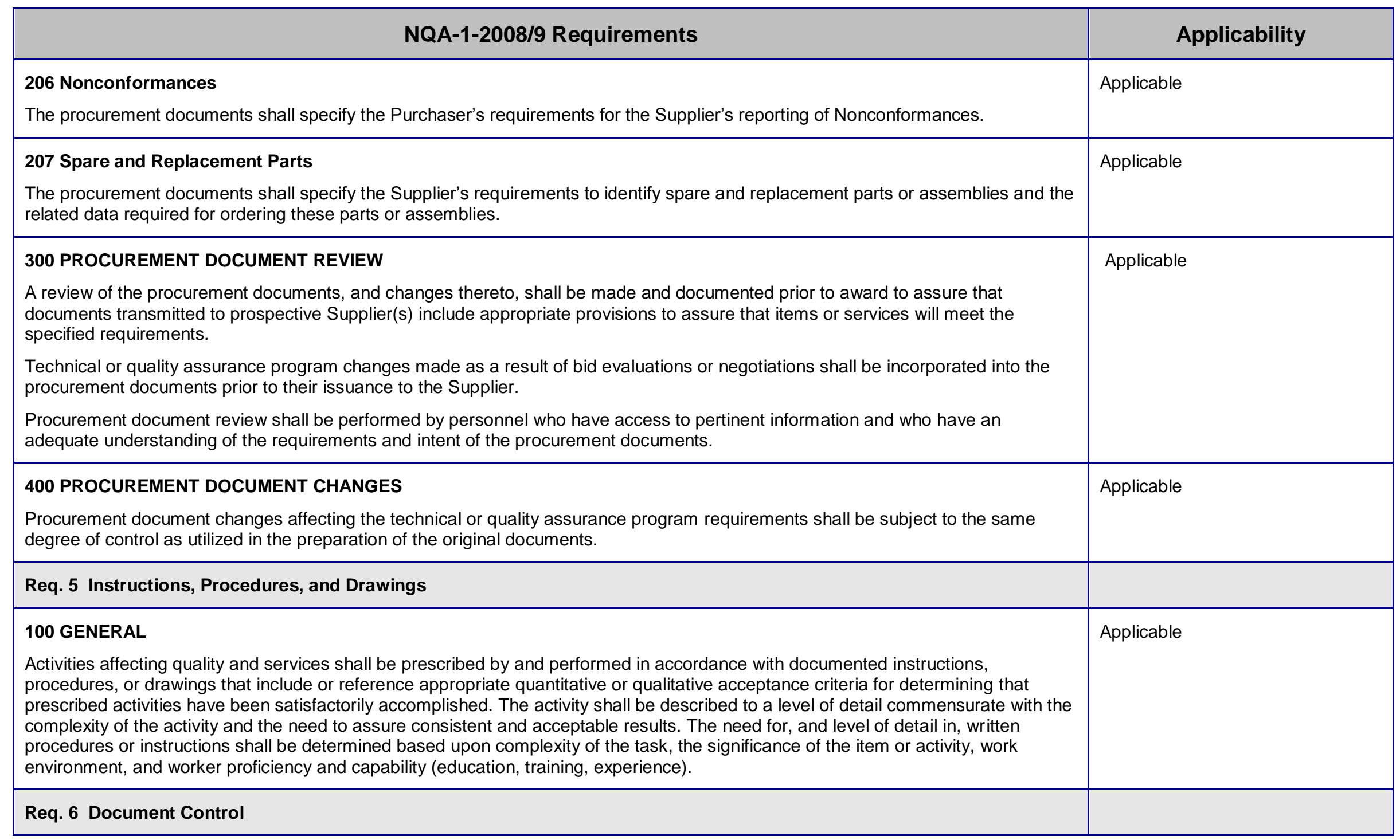




\section{Appendix A: Evaluation of Applicability of NQA-1 to SFR Metallic Fuel Historical Data Qualification Process}

\begin{tabular}{|c|c|}
\hline NQA-1-2008/9 Requirements & Applicability \\
\hline $\begin{array}{l}100 \text { GENERAL } \\
\text { The preparation, issue, and change of documents that specify quality requirements or prescribe activities affecting quality such as } \\
\text { instructions, procedures, and drawings shall be controlled to ensure that correct documents are being employed. Such documents, } \\
\text { including changes thereto, shall be reviewed for adequacy and approved for release by authorized personnel. }\end{array}$ & $\begin{array}{l}\text { Applicable, Data qualification } \\
\text { documents will be controlled by the } \\
\text { ANL document control procedures } \\
\text { meeting. }\end{array}$ \\
\hline $\begin{array}{l}200 \text { DOCUMENT CONTROL } \\
\text { The following controls shall be applied to documents and changes thereto: } \\
\text { (a) the identification of controlled documents } \\
\text { (b) the specified distribution of controlled documents for use at the appropriate location } \\
\text { (c) the identification of individuals responsible for the preparation, review, approval, and distribution of controlled documents } \\
\text { (d) the review of controlled documents for adequacy, completeness, and approval prior to distribution } \\
\text { (e) a method to ensure the correct documents are being used }\end{array}$ & Applicable \\
\hline $\begin{array}{l}300 \text { DOCUMENT CHANGES } \\
301 \text { Major Changes } \\
\text { Changes to documents, other than those defined as minor changes, are considered major changes and shall be reviewed and } \\
\text { approved by the same organizations that performed the original review and approval unless other organizations are specifically } \\
\text { designated. The reviewing organization shall have access to pertinent background data or information upon which to base their } \\
\text { approval. }\end{array}$ & Applicable \\
\hline $\begin{array}{l}302 \text { Minor Changes } \\
\text { Minor changes to documents, such as inconsequential editorial corrections, shall not require that the revised documents receive the } \\
\text { same review and approval as the original documents. To avoid a possible omission of a required review, the type of minor changes } \\
\text { that do not require such a review and approval and the persons who can authorize such a decision shall be clearly delineated. }\end{array}$ & Applicable \\
\hline Req. 7 Control of Purchased Items and Services & \\
\hline $\begin{array}{l}100 \text { GENERAL } \\
\text { The procurement of items and services shall be controlled to ensure conformance with specified requirements. Such control shall } \\
\text { provide for the following as appropriate: source evaluation and selection, evaluation of objective evidence of quality furnished by the } \\
\text { Supplier, source inspection, audit, and examination of items or services upon delivery or completion. }\end{array}$ & Applicable \\
\hline
\end{tabular}




\section{Appendix A: Evaluation of Applicability of NQA-1 to SFR Metallic Fuel Historical Data Qualification Process}

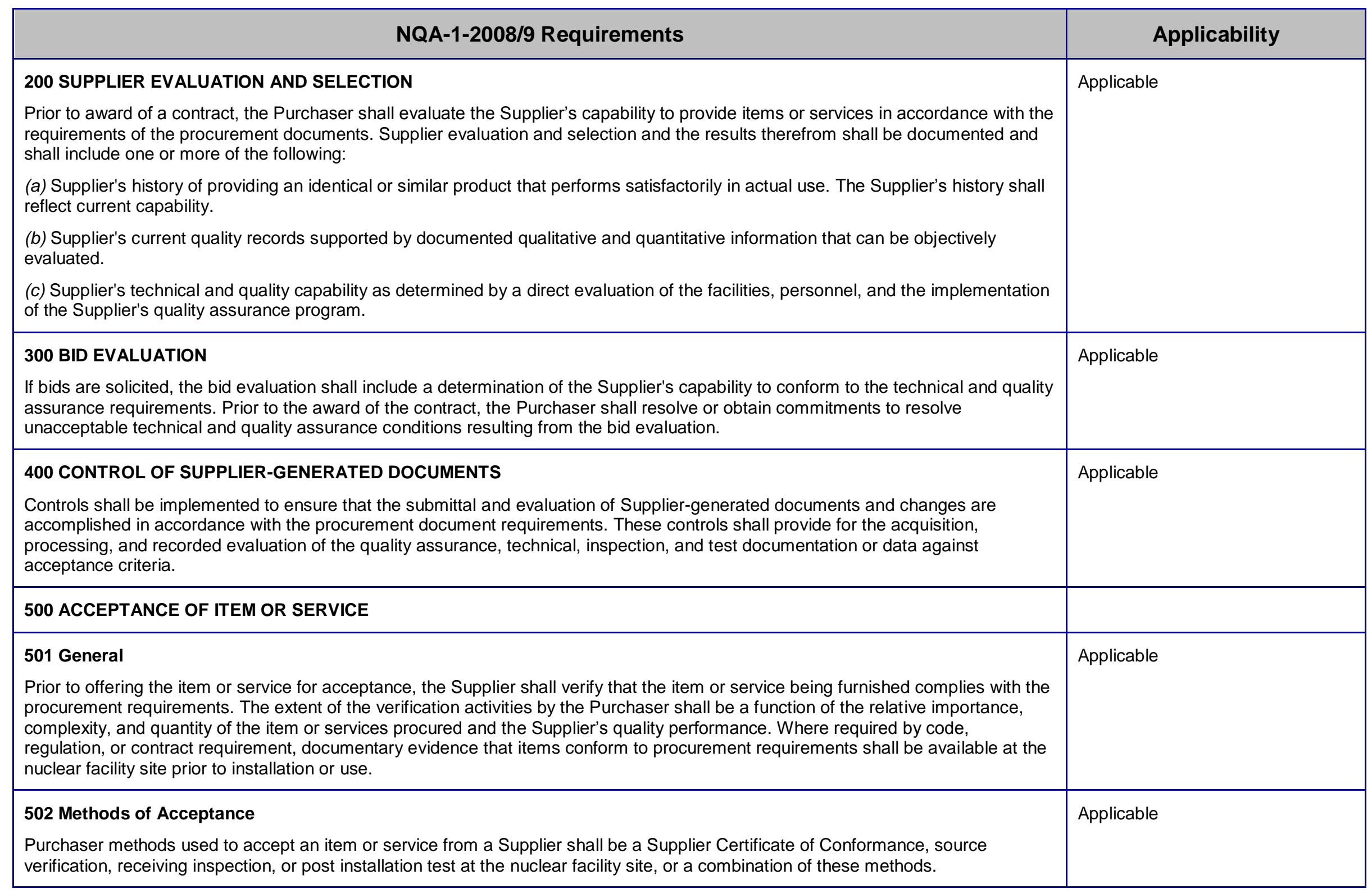




\section{Appendix A: Evaluation of Applicability of NQA-1 to SFR Metallic Fuel Historical Data Qualification Process}

\begin{tabular}{|c|c|}
\hline NQA-1-2008/9 Requirements & Applicability \\
\hline $\begin{array}{l}503 \text { Certificate of Conformance } \\
\text { When a Certificate of Conformance is used, the minimum criteria of paras. 503(a) through (f) of this Requirement shall be met. } \\
\text { (a) The certificate shall identify the purchased material or equipment, such as by the purchase order number. } \\
\text { (b) The certificate shall identify the specific procurement requirements met by the purchased material or equipment such as codes, } \\
\text { standards, and other specifications. This may be accomplished by including a list of the specific requirements or by providing, on- } \\
\text { site, a copy of the purchase order and the procurement specifications or drawings, together with a suitable certificate. The } \\
\text { procurement requirements identified shall include any approved changes, waivers, or deviations applicable to the subject material or } \\
\text { equipment. } \\
\text { (c) The certificate shall identify any procurement requirements that have not been met, together with an explanation and the means } \\
\text { for resolving the nonconformances. } \\
\text { (d) The certificate shall be signed or otherwise authenticated by a person who is responsible for this quality assurance function and } \\
\text { whose function and position are described in the Purchaser's or Supplier's quality assurance program. } \\
\text { (e) The certification system, including the procedures to be followed in filling out a certificate and the administrative procedures for } \\
\text { review and approval of the certificates, shall be described in the Purchaser's or Supplier's quality assurance program. } \\
\text { (f) Means shall be provided to verify the validity of Supplier certificates and the effectiveness of the certification system, such as } \\
\text { during the performance of audits of the Supplier or independent inspection or test of the items. Such verification shall be conducted } \\
\text { by the Purchaser at intervals commensurate with the Supplier's past quality performance. }\end{array}$ & Applicable \\
\hline $\begin{array}{l}504 \text { Source Verification } \\
\text { When source verification is used, it shall be performed at intervals consistent with the importance and complexity of the item or } \\
\text { service, and shall include monitoring, witnessing, or observing selected activities. Source verification shall be implemented in } \\
\text { accordance with plans to perform inspections, examinations, or tests at predetermined points. Upon Purchaser acceptance of source } \\
\text { verification, documented evidence of acceptance shall be furnished to the receiving destination of the item, to the Purchaser, and to } \\
\text { the Supplier. }\end{array}$ & Applicable \\
\hline $\begin{array}{l}505 \text { Receiving Inspection } \\
\text { When receiving inspection is used, purchased items shall be inspected as necessary to verify conformance to specified } \\
\text { requirements, taking into account source verification and audit activities and the demonstrated quality performance of the Supplier. } \\
\text { Receiving inspection shall verify by objective evidence such features such as } \\
\text { (a) configuration } \\
\text { (b) identification } \\
\text { (c) dimensional, physical, and other characteristics }\end{array}$ & Applicable \\
\hline
\end{tabular}




\section{Appendix A: Evaluation of Applicability of NQA-1 to SFR Metallic Fuel Historical Data Qualification Process}

\begin{tabular}{|c|c|}
\hline NQA-1-2008/9 Requirements & Applicability \\
\hline $\begin{array}{l}\text { (d) freedom from shipping damage } \\
\text { (e) cleanliness } \\
\text { Receiving inspection shall be coordinated with review of Supplier documentation when procurement documents require such } \\
\text { documentation to be furnished prior to receiving inspection. }\end{array}$ & \\
\hline $\begin{array}{l}506 \text { Post-installation Testing } \\
\text { When post installation testing is used, post installation test requirements and acceptance documentation shall be mutually } \\
\text { established by the Purchaser and Supplier. }\end{array}$ & Applicable \\
\hline $\begin{array}{l}507 \text { Acceptance of Services Only } \\
\text { In cases involving procurement of services only, such as third-party inspection; engineering and consulting services; auditing; and } \\
\text { installation, repair, overhaul, or maintenance work, the Purchaser shall accept the service by any or all of the following methods: } \\
\text { (a) technical verification of data produced } \\
\text { (b) surveillance and/or audit of the activity } \\
\text { (c) review of objective evidence for conformance to the procurement document requirements }\end{array}$ & Applicable \\
\hline $\begin{array}{l}600 \text { CONTROL OF SUPPLIER NONCONFORMANCES } \\
\text { Methods for control and disposition of Supplier nonconformance for items and services that do not meet procurement document } \\
\text { requirements shall include paras. } 600(\mathrm{a}) \text { through (e) of this Requirement: } \\
\text { (a) evaluation of nonconforming items. } \\
\text { (b) submittal of nonconformance notice to Purchaser by Supplier as directed by the Purchaser. These submittals shall include } \\
\text { Supplier-recommended disposition (e.g., use-as-is or repair) and technical justification. Nonconformances to the procurement } \\
\text { requirements or Purchaser-approved documents, which consist of one or more of the following, shall be submitted to the Purchaser } \\
\text { for approval of the recommended disposition: } \\
\text { (1) technical or material requirement is violated } \\
\text { (2) requirement in Supplier documents, which has been approved by the Purchaser, is violated } \\
\text { (3) nonconformance cannot be corrected by continuation of the original manufacturing process or by rework } \\
\text { (4) the item does not conform to the original requirement even though the item can be restored to a condition such that the } \\
\text { capability of the item to function is unimpaired } \\
\text { (c) Purchaser disposition of Supplier recommendation. } \\
\text { (d) verification of the implementation of the disposition. }\end{array}$ & Applicable \\
\hline
\end{tabular}




\section{Appendix A: Evaluation of Applicability of NQA-1 to SFR Metallic Fuel Historical Data Qualification Process}

\begin{tabular}{|c|c|}
\hline NQA-1-2008/9 Requirements & Applicability \\
\hline \multicolumn{2}{|l|}{ (e) maintenance of records of Supplier-submitted nonconformances. } \\
\hline $\begin{array}{l}700 \text { COMMERCIAL GRADE ITEMS AND SERVICES } \\
\text { When commercial grade items or services are utilized, the requirements of Part II, Subpart 2.14, Quality Assurance Requirements fo } \\
\text { Commercial Grade Items and Services, shall apply and are an acceptable alternative to sections } 200 \text { through } 600 \text { of this } \\
\text { Requirement, except that Supplier evaluation and selection, where determined necessary by the Purchaser, shall be in accordance } \\
\text { with section } 200 \text { of this Requirement. }\end{array}$ & Applicable \\
\hline $\begin{array}{l}800 \text { RECORDS } \\
\text { Records shall be established and maintained to indicate the performance of the following functions: } \\
\text { (a) supplier evaluation and selection } \\
\text { (b) acceptance of items or services } \\
\text { (c) supplier nonconformances to procurement document requirements, including their evaluation and disposition }\end{array}$ & Applicable \\
\hline \multicolumn{2}{|l|}{ Req. 8 Identification and Control of Items } \\
\hline $\begin{array}{l}100 \text { GENERAL } \\
\text { Controls shall be established to assure that only correct and accepted items are used or installed. } \\
\text { Identification shall be maintained on the items or in documents traceable to the items, or in a manner that assures that identification } \\
\text { is established and maintained. }\end{array}$ & Not Applicable \\
\hline \multicolumn{2}{|l|}{200 IDENTIFICATION METHODS } \\
\hline $\begin{array}{l}201 \text { Item Identification } \\
\text { Items of production (batch, lot, component, part) shall be identified from the initial receipt and fabrication of items up to and including } \\
\text { installation and use. This identification shall relate an item to an applicable design or other pertinent specifying document. }\end{array}$ & Not Applicable \\
\hline $\begin{array}{l}202 \text { Physical Identification } \\
\text { Physical identification shall be used to the maximum extent possible. Where physical identification on the item is either impractical or } \\
\text { insufficient, physical separation, procedural control, or other appropriate means shall be employed. Identification markings shall be } \\
\text { applied using materials and methods that provide a clear and legible identification and do not degrade the function or service life of } \\
\text { the item. Markings shall be transferred to each part of an identified item when subdivided and shall not be obliterated or hidden by } \\
\text { surface treatment or coating unless other means of identification are substituted. }\end{array}$ & Not Applicable \\
\hline
\end{tabular}




\section{Appendix A: Evaluation of Applicability of NQA-1 to SFR Metallic Fuel Historical Data Qualification Process}

\begin{tabular}{|c|c|}
\hline NQA-1-2008/9 Requirements & Applicability \\
\hline \multicolumn{2}{|l|}{300 SPECIFIC REQUIREMENTS } \\
\hline $\begin{array}{l}301 \text { Identification and Traceability of Items } \\
\text { When codes, standards, or specifications include specific identification or traceability requirements (such as identification or } \\
\text { traceability of the item to applicable specification and grade of material; heat, batch, lot, part, or serial number; or specified } \\
\text { inspection, test, or other records), the program shall provide such identification and traceability control. }\end{array}$ & Not Applicable \\
\hline $\begin{array}{l}302 \text { Limited Life Items } \\
\text { Items having limited calendar or operating life or cycles shall be identified and controlled to preclude use of items whose shelf life or } \\
\text { operating life has expired. }\end{array}$ & Not Applicable \\
\hline $\begin{array}{l}303 \text { Maintaining Identification of Stored Items } \\
\text { Provisions shall be made for the control of item identification consistent with the planned duration and conditions of storage, such as } \\
\text { (a) provisions for maintenance or replacement of markings and identification records due to damage during handling or aging } \\
\text { (b) protection of identifications on items subject to excessive deterioration due to environmental exposure } \\
\text { (c) provisions for updating existing plant records }\end{array}$ & Not Applicable \\
\hline \multicolumn{2}{|l|}{ Req. 9 Control of Special Processes } \\
\hline $\begin{array}{l}100 \text { GENERAL } \\
\text { Special processes that control or verify quality, such as those used in welding, heat treating, and nondestructive examination, shall } \\
\text { be performed by qualified personnel using qualified procedures in accordance with specified requirements. }\end{array}$ & Not Applicable \\
\hline 200 PROCESS CONTROL & \\
\hline $\begin{array}{l}201 \text { Special Processes } \\
\text { Special processes shall be controlled by instructions, procedures, drawings, checklists, travelers, or other appropriate means. } \\
\text { Special process instructions shall include or reference procedure, personnel, and equipment qualification requirements. Conditions } \\
\text { necessary for accomplishment of the process shall be included. These conditions shall include proper equipment, controlled } \\
\text { parameters of the process, specified environment, and calibration requirements. }\end{array}$ & Not Applicable \\
\hline $\begin{array}{l}202 \text { Acceptance Criteria } \\
\text { The requirements of applicable codes and standards, including acceptance criteria for the process, shall be specified or referenced } \\
\text { in procedures or instructions. }\end{array}$ & Not Applicable \\
\hline
\end{tabular}




\section{Appendix A: Evaluation of Applicability of NQA-1 to SFR Metallic Fuel Historical Data Qualification Process}

\begin{tabular}{|c|c|}
\hline NQA-1-2008/9 Requirements & Applicability \\
\hline $\begin{array}{l}203 \text { Special Requirements } \\
\text { For special processes not covered by existing codes and standards or where quality requirements specified exceed those of existing } \\
\text { codes or standards, the necessary requirements for qualifications of personnel, procedures, or equipment shall be specified or } \\
\text { referenced in procedures or instructions. }\end{array}$ & Not Applicable \\
\hline $\begin{array}{l}300 \text { RESPONSIBILITY } \\
\text { It is the responsibility of the organization performing the special process to adhere to the approved procedures and processes. }\end{array}$ & Not Applicable \\
\hline $\begin{array}{l}400 \text { RECORDS } \\
\text { Records shall be maintained as appropriate for the currently qualified personnel, processes, and equipment of each special process. }\end{array}$ & Not Applicable \\
\hline Req. 10 Inspection & \\
\hline $\begin{array}{l}100 \text { GENERAL } \\
\text { Inspections required to verify conformance of an item or activity to specified requirements or continued acceptability of items in } \\
\text { service shall be planned and executed. Characteristics subject to inspection and inspection methods shall be specified. Inspection } \\
\text { results shall be documented. Inspection for acceptance shall be performed by qualified persons other than those who performed or } \\
\text { directly supervised the work being inspected. }\end{array}$ & Not Applicable \\
\hline $\begin{array}{l}200 \text { INSPECTION REQUIREMENTS } \\
\text { Inspection requirements and acceptance criteria shall include specified requirements contained in the applicable design documents } \\
\text { or other pertinent technical documents approved by the responsible design organization. }\end{array}$ & Not Applicable \\
\hline $\begin{array}{l}300 \text { INSPECTION HOLD POINTS } \\
\text { If mandatory inspection hold points are required beyond which work shall not proceed without the specific consent of the designated } \\
\text { representative, the specific hold points shall be indicated in appropriate documents. Consent to waive specified hold points shall be } \\
\text { recorded prior to continuation of work beyond the designated hold point. }\end{array}$ & Not Applicable \\
\hline 400 INSPECTION PLANNING & Not Applicable \\
\hline $\begin{array}{l}401 \text { Planning } \\
\text { Characteristics to be inspected, methods of inspection, and acceptance criteria shall be identified during the inspection planning } \\
\text { process. }\end{array}$ & Not Applicable \\
\hline
\end{tabular}




\section{Appendix A: Evaluation of Applicability of NQA-1 to SFR Metallic Fuel Historical Data Qualification Process}

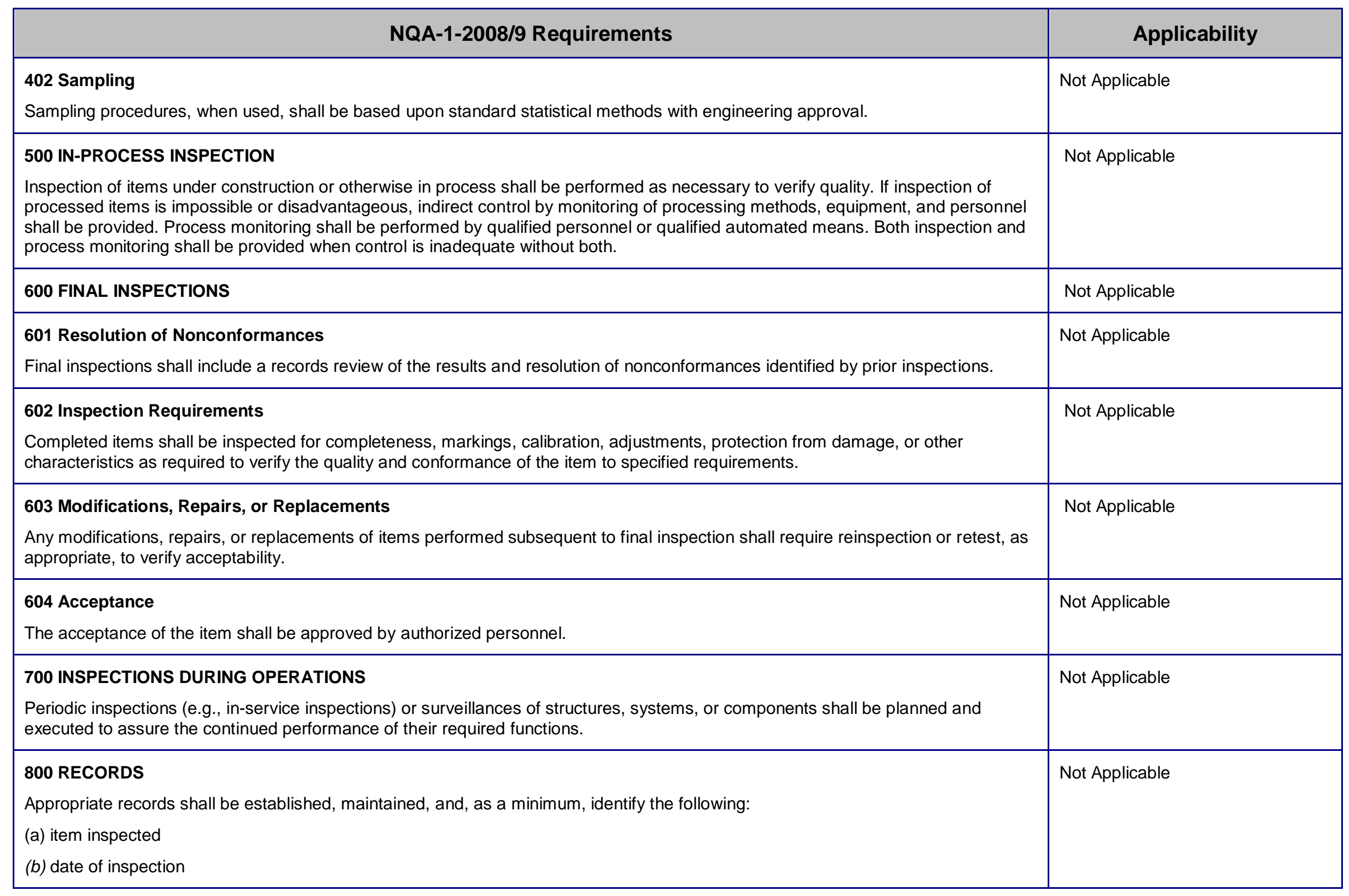




\section{Appendix A: Evaluation of Applicability of NQA-1 to SFR Metallic Fuel Historical Data Qualification Process}

\begin{tabular}{|c|c|}
\hline NQA-1-2008/9 Requirements & Applicability \\
\hline $\begin{array}{l}\text { (c) inspector } \\
\text { (d) type of observation } \\
\text { (e) results or acceptability } \\
\text { (f) reference to information on action taken in connection with nonconformances }\end{array}$ & \\
\hline Req. 11 Test Control & \\
\hline $\begin{array}{l}100 \text { GENERAL } \\
\text { Tests required to collect data such as for siting or design input, to verify conformance of an item or computer program to specified } \\
\text { requirements, or to demonstrate satisfactory performance for service shall be planned and executed. Characteristics to be tested } \\
\text { and test methods to be employed shall be specified. Test results shall be documented and their conformance with test requirements } \\
\text { and acceptance criteria shall be evaluated. }\end{array}$ & Not Applicable \\
\hline $\begin{array}{l}200 \text { TEST REQUIREMENTS } \\
\text { (a) Test requirements and acceptance criteria shall be provided or approved by the responsible design organization. Required tests } \\
\text { (other than for computer programs) including, as appropriate, prototype qualification tests, production tests, proof tests prior to } \\
\text { installation, construction tests, preoperational tests, and operational tests shall be controlled. Computer program tests including, as } \\
\text { appropriate, software design verification, factory acceptance tests, site acceptance tests, and in-use tests shall be controlled. } \\
\text { Required tests shall be controlled under appropriate environmental conditions using the tools and equipment necessary to conduct } \\
\text { the test in a manner to fulfill test requirements and acceptance criteria. The tests performed shall obtain the necessary data with } \\
\text { sufficient accuracy for evaluation and acceptance. } \\
\text { (b) Test requirements and acceptance criteria shall be based upon specified requirements contained in applicable design } \\
\text { documents, or other pertinent technical documents that provide approved requirements. } \\
\text { (c) If temporary changes to the approved configuration of a facility are required for testing purposes, approval by the design authority } \\
\text { is required prior to performing the test. }\end{array}$ & Not Applicable \\
\hline
\end{tabular}




\section{Appendix A: Evaluation of Applicability of NQA-1 to SFR Metallic Fuel Historical Data Qualification Process}

\begin{tabular}{|c|c|}
\hline NQA-1-2008/9 Requirements & Applicability \\
\hline $\begin{array}{l}300 \text { TEST PROCEDURES (OTHER THAN FOR COMPUTER PROGRAMS) } \\
\text { (a) Test procedures shall include or reference the test configuration and test objectives. Test procedures shall also include provisions } \\
\text { for assuring that prerequisites and suitable environmental conditions are met, adequate instrumentation is available and used, } \\
\text { appropriate tests and equipment are used, and necessary monitoring is performed. Prerequisites shall include the following, as } \\
\text { applicable: } \\
\text { (1) calibrated instrumentation } \\
\text { (2) appropriate equipment } \\
\text { (3) trained personnel } \\
\text { (4) condition of test equipment and the item to be tested } \\
\text { (5) suitable environmental conditions } \\
\text { (6) provisions for data acquisition } \\
\text { (b) As an alternative to para. } 300 \text { (a) of this Requirement, appropriate sections of related documents, such as ASTM methods, } \\
\text { Supplier manuals, equipment maintenance instructions, or approved drawings or travelers with acceptance criteria, may be used. } \\
\text { Such documents shall include or be supplemented with appropriate criteria from para. } 300 \text { (a) to assure adequate procedures for the } \\
\text { test are used. }\end{array}$ & Not Applicable \\
\hline $\begin{array}{l}400 \text { COMPUTER PROGRAM TEST PROCEDURES } \\
\text { The requirements of section } 400 \text { of Requirement } 11 \text { apply, instead of section 300, Test Procedures, to testing of computer programs, } \\
\text { and as appropriate, the computer hardware and operating system. } \\
\text { (a) Computer program test procedures shall provide for demonstrating the adherence of the computer program to documented } \\
\text { requirements. For those computer programs used in design activities, computer program test procedures shall provide for assuring } \\
\text { that the computer program produces correct results. For those computer programs used for operational control, computer program } \\
\text { test procedures shall provide for demonstrating required performance over the range of operation of the controlled function or } \\
\text { process. The procedures shall also provide for evaluating technical adequacy through comparison of test results from alternative } \\
\text { methods such as hand calculations, calculations using comparable proven programs, or empirical data and information from } \\
\text { technical literature. } \\
\text { (b) In-use test procedures shall be developed and documented to permit confirmation of acceptable performance of the computer } \\
\text { program in the operating system. } \\
\text { In-use test procedures shall be performed after the computer program is installed on a different computer, or when there are } \\
\text { significant changes in the operating system. } \\
\text { Periodic in-use manual or automatic self-check in-use tests shall be prescribed and performed for those computer programs in which } \\
\text { computer program errors, data errors, computer hardware failures, or instrument drift can affect required performance. }\end{array}$ & Not Applicable \\
\hline
\end{tabular}




\section{Appendix A: Evaluation of Applicability of NQA-1 to SFR Metallic Fuel Historical Data Qualification Process}

\begin{tabular}{|c|c|}
\hline NQA-1-2008/9 Requirements & Applicability \\
\hline $\begin{array}{l}500 \text { TEST RESULTS } \\
\text { Test results shall be documented and maintained. Test results shall be evaluated by the responsible authority to ensure that test } \\
\text { requirements have been satisfied. }\end{array}$ & Not Applicable \\
\hline $\begin{array}{l}600 \text { TEST RECORDS } \\
\text { Test records shall be established and maintained to indicate the ability of the item or computer program to satisfactorily perform its } \\
\text { intended function or to meet its documented requirements. Test records vary depending on the test type, purpose, and application } \\
\text { but shall contain the following information, as a minimum, for the specified application identified in paras. } 601 \text { and } 602 \text {. }\end{array}$ & Not Applicable \\
\hline $\begin{array}{l}601 \text { Test Records } \\
\text { (a) item tested } \\
\text { (b) date of test } \\
\text { (c) tester or data recorder } \\
\text { (d) type of observation } \\
\text { (e) results and acceptability } \\
\text { (f) action taken in connection with any deviations } \\
\text { (g) person evaluating test results }\end{array}$ & Not Applicable \\
\hline
\end{tabular}




\section{Appendix A: Evaluation of Applicability of NQA-1 to SFR Metallic Fuel Historical Data Qualification Process}

\begin{tabular}{|c|c|}
\hline NQA-1-2008/9 Requirements & Applicability \\
\hline $\begin{array}{l}602 \text { Computer Program Test Records } \\
\text { (a) Verification Test Records } \\
\text { (1) computer program tested } \\
\text { (2) computer hardware tested } \\
\text { (3) test equipment and calibrations, where applicable } \\
\text { (4) date of test } \\
\text { (5) tester or data recorder } \\
\text { (6) simulation models used, where applicable } \\
\text { (7) test problems } \\
\text { (8) results and applicability } \\
\text { (9) action taken in connection with any deviations } \\
\text { noted } \\
\text { (10) person evaluating test results } \\
\text { (b) In-Use Test Records } \\
\text { (1) computer program tested } \\
\text { (2) computer hardware tested } \\
\text { (3) test equipment and calibrations, where applicable } \\
\text { (4) date of test } \\
\text { (5) tester or data recorder } \\
\text { (6) acceptability }\end{array}$ & Not Applicable \\
\hline Req. 12 Control of Measuring and Test Equipment & \\
\hline $\begin{array}{l}100 \text { GENERAL } \\
\text { Tools, gages, instruments, and other measuring and test equipment used for activities affecting quality shall be controlled, calibrated } \\
\text { at specific periods, adjusted, and maintained to required accuracy limits. }\end{array}$ & Not Applicable \\
\hline
\end{tabular}




\section{Appendix A: Evaluation of Applicability of NQA-1 to SFR Metallic Fuel Historical Data Qualification Process}

\begin{tabular}{|c|c|}
\hline NQA-1-2008/9 Requirements & Applicability \\
\hline $\begin{array}{l}200 \text { SELECTION } \\
\text { Selection of measuring and test equipment shall be based on the type, range, accuracy, and tolerance needed to accomplish the } \\
\text { required measurements for determining conformance to specified requirements. }\end{array}$ & Not Applicable \\
\hline 300 CALIBRATION AND CONTROL & \\
\hline $\begin{array}{l}301 \text { Calibration } \\
\text { Measuring and test equipment shall be calibrated, at prescribed times or intervals and whenever the accuracy of the measuring and } \\
\text { test equipment is suspect. Calibration shall be against and traceable to certified equipment or reference standards having known } \\
\text { valid relationships to nationally recognized standards, or to international standards known to be equivalent to and verified against } \\
\text { corresponding nationally recognized standards. Where no such standards exist, the basis for calibration shall be defined. }\end{array}$ & Not Applicable \\
\hline $\begin{array}{l}302 \text { Reference Standards } \\
\text { Reference standards shall have a minimum accuracy four times greater than that of the measuring and test equipment being } \\
\text { calibrated to ensure that the reference standards contribute no more than one-fourth of the allowable calibration tolerance. Where } \\
\text { this } 4 \text { :I ratio cannot be maintained, the basis for selection of the standard in question shall be technically justified. }\end{array}$ & Not Applicable \\
\hline $\begin{array}{l}303 \text { Control } \\
\text { Calibration procedures shall identify or reference required accuracy and shall define methods and frequency of checking accuracy. } \\
\text { The calibration method and interval of calibration shall be based on the type of equipment, stability characteristics, required } \\
\text { accuracy, intended use, and other conditions affecting performance. Measuring and test equipment, which is overdue for calibration } \\
\text { or found to be out-of-calibration, shall be tagged and/or segregated, or removed from service, and not used until it has been } \\
\text { recalibrated. Measuring or test equipment found to be out-of-calibration shall be repaired or replaced. }\end{array}$ & Not Applicable \\
\hline $\begin{array}{l}\text { 303.1 Application } \\
\text { Measuring and test equipment shall be traceable to its application and use. }\end{array}$ & Not Applicable \\
\hline $\begin{array}{l}\text { 303.2 Corrective Action } \\
\text { When measuring and test equipment is lost, damaged, or found to be out-of-calibration, the validity of previous measurement, } \\
\text { inspection, or test results, and the acceptability of items previously inspected or tested shall be evaluated. This evaluation shall be } \\
\text { from at least the last acceptable calibration of the M\&TE. The evaluation and resulting actions shall be commensurate with the } \\
\text { significance of the condition. }\end{array}$ & Not Applicable \\
\hline 303.3 Handling and Storage & Not Applicable \\
\hline
\end{tabular}




\section{Appendix A: Evaluation of Applicability of NQA-1 to SFR Metallic Fuel Historical Data Qualification Process}

\begin{tabular}{|c|c|}
\hline NQA-1-2008/9 Requirements & Applicability \\
\hline \multicolumn{2}{|l|}{ Measuring and test equipment shall be properly handled and stored to maintain accuracy. } \\
\hline $\begin{array}{l}\text { 303.4 Environmental Controls } \\
\text { Measuring and test equipment shall be used and calibrated in environments that are controlled to the extent necessary to ensure } \\
\text { that the required accuracy and precision are maintained. }\end{array}$ & Not Applicable \\
\hline $\begin{array}{l}\text { 303.5 Precalibration Checks } \\
\text { Measuring and test equipment and reference standards submitted for calibration shall be checked and the results recorded befor } \\
\text { any required adjustments or repairs are made. }\end{array}$ & Not Applicable \\
\hline $\begin{array}{l}\text { 303.6 Status Indication } \\
\text { Measuring and test equipment shall be suitably marked, tagged, labeled, or otherwise identified to indicate calibration status and } \\
\text { establish traceability to calibration records. }\end{array}$ & Not Applicable \\
\hline $\begin{array}{l}304 \text { Commercial Devices } \\
\text { Calibration and control measures are not required for commercial equipment such as rulers, tape measures, levels, etc., if such } \\
\text { equipment provides the required accuracy. }\end{array}$ & Not Applicable \\
\hline $\begin{array}{l}400 \text { RECORDS } \\
401 \text { General } \\
\text { Records shall be established and maintained to indicate calibration status and the capability of measuring and test equipment to } \\
\text { satisfactorily perform its intended function. }\end{array}$ & Not Applicable \\
\hline $\begin{array}{l}402 \text { Reports and Certificates } \\
\text { Calibration reports and certificates reporting the results of calibrations shall include the information and data necessary for } \\
\text { interpretation of the calibration results and verification of conformance to applicable requirements. }\end{array}$ & Not Applicable \\
\hline Req. 13 Handling, Storage, and Shipping & \\
\hline $\begin{array}{l}100 \text { GENERAL } \\
\text { Handling, storage, cleaning, packaging, shipping, and preservation of items shall be controlled to prevent damage or loss and to } \\
\text { minimize deterioration. These activities shall be conducted in accordance with established work and inspection instructions, } \\
\text { drawings, specifications, shipment instructions, or other pertinent documents or procedures specified for use in conducting the } \\
\text { activity. }\end{array}$ & Not Applicable \\
\hline
\end{tabular}




\section{Appendix A: Evaluation of Applicability of NQA-1 to SFR Metallic Fuel Historical Data Qualification Process}

\begin{tabular}{|c|c|}
\hline NQA-1-2008/9 Requirements & Applicability \\
\hline $\begin{array}{l}200 \text { SPECIAL REQUIREMENTS } \\
\text { When required, special equipment (such as containers, shock absorbers, and accelerometers) and special protective environments } \\
\text { (such as inert gas atmosphere, specific moisture content levels, and temperature levels) shall be specified and provided and their } \\
\text { existence verified. }\end{array}$ & Not Applicable \\
\hline $\begin{array}{l}300 \text { PROCEDURES } \\
\text { When required for critical, sensitive, perishable, or high-value items, specific procedures for handling, storage, packaging, shipping, } \\
\text { and preservation shall be used. }\end{array}$ & Not Applicable \\
\hline $\begin{array}{l}400 \text { TOOLS AND EQUIPMENT } \\
\text { Special handling tools and equipment shall be utilized and controlled where necessary to ensure safe and adequate handling. } \\
\text { Special handling tools and equipment shall be inspected and tested in accordance with procedures at specified time intervals or prior } \\
\text { to use. }\end{array}$ & Not Applicable \\
\hline $\begin{array}{l}500 \text { OPERATORS } \\
\text { Operators of special handling and lifting equipment shall be experienced or trained in the use of the equipment. }\end{array}$ & Not Applicable \\
\hline $\begin{array}{l}600 \text { MARKING OR LABELING } \\
\text { Marking or labeling shall be utilized as necessary to adequately maintain and preserve the item, including indication of the presence } \\
\text { of special environments or the need for special controls. }\end{array}$ & Not Applicable \\
\hline Req. 14 Inspection, Test, and Operating Status & \\
\hline $\begin{array}{l}100 \text { GENERAL } \\
\text { The status of inspection and test activities shall be identified either on the items or in documents traceable to the items where it is } \\
\text { necessary to ensure that required inspections and tests are performed and to ensure that items that have not passed the required } \\
\text { inspections and tests are not inadvertently installed, used, or operated. Status shall be maintained through indicators, such as } \\
\text { physical location and tags, markings, shop travelers, stamps, inspection records, or other suitable means. The authority for } \\
\text { application and removal of tags, markings, labels, and stamps shall be specified. Status indicators shall also provide for indicating } \\
\text { the operating status of systems and components of the nuclear facility, such as by tagging valves and switches, to prevent } \\
\text { inadvertent operation. }\end{array}$ & Not Applicable \\
\hline Req. 15 Control of Nonconforming Items & \\
\hline
\end{tabular}




\section{Appendix A: Evaluation of Applicability of NQA-1 to SFR Metallic Fuel Historical Data Qualification Process}

\begin{tabular}{|c|c|}
\hline NQA-1-2008/9 Requirements & Applicability \\
\hline $\begin{array}{l}100 \text { GENERAL } \\
\text { Items that do not conform to specified requirements shall be controlled to prevent inadvertent installation or use. Controls shall } \\
\text { provide for identification, documentation, evaluation, segregation when practical, and disposition of nonconforming items, and for } \\
\text { notification to affected organizations. }\end{array}$ & Applicable \\
\hline $\begin{array}{l}200 \text { IDENTIFICATION } \\
\text { Nonconforming items shall be identified by legible marking, tagging, or other methods not detrimental to the item, on either the item } \\
\text { the container, or the package containing the item. }\end{array}$ & Applicable \\
\hline $\begin{array}{l}300 \text { SEGREGATION } \\
\text { (a) Nonconforming items shall be segregated, when practical, by placing them in a clearly identified and designated hold area until } \\
\text { properly dispositioned. } \\
\text { (b) When segregation is impractical or impossible due to physical conditions such as size, weight, or access limitations, other } \\
\text { precautions shall be employed to preclude inadvertent use of a nonconforming item. }\end{array}$ & Applicable \\
\hline 400 DISPOSITION & \\
\hline $\begin{array}{l}401 \text { Control } \\
\text { Nonconforming items shall be evaluated and recommended dispositions shall be proposed. Further processing, delivery, installatio } \\
\text { or use of a nonconforming item shall be controlled pending the evaluation and an approved disposition by authorized personnel. }\end{array}$ & Applicable \\
\hline $\begin{array}{l}402 \text { Responsibility and Authority } \\
\text { The responsibility and authority for the evaluation and disposition of nonconforming items shall be defined. Responsibility for the } \\
\text { control of further processing, delivery, installation, or use of nonconforming items shall be designated in writing. }\end{array}$ & Applicable \\
\hline $\begin{array}{l}403 \text { Personnel } \\
\text { Personnel performing evaluations to determine a disposition shall have } \\
\text { (a) demonstrated competence in the specific area they are evaluating } \\
\text { (b) an adequate understanding of the requirements } \\
\text { (c) access to pertinent background information }\end{array}$ & Applicable \\
\hline
\end{tabular}




\section{Appendix A: Evaluation of Applicability of NQA-1 to SFR Metallic Fuel Historical Data Qualification Process}

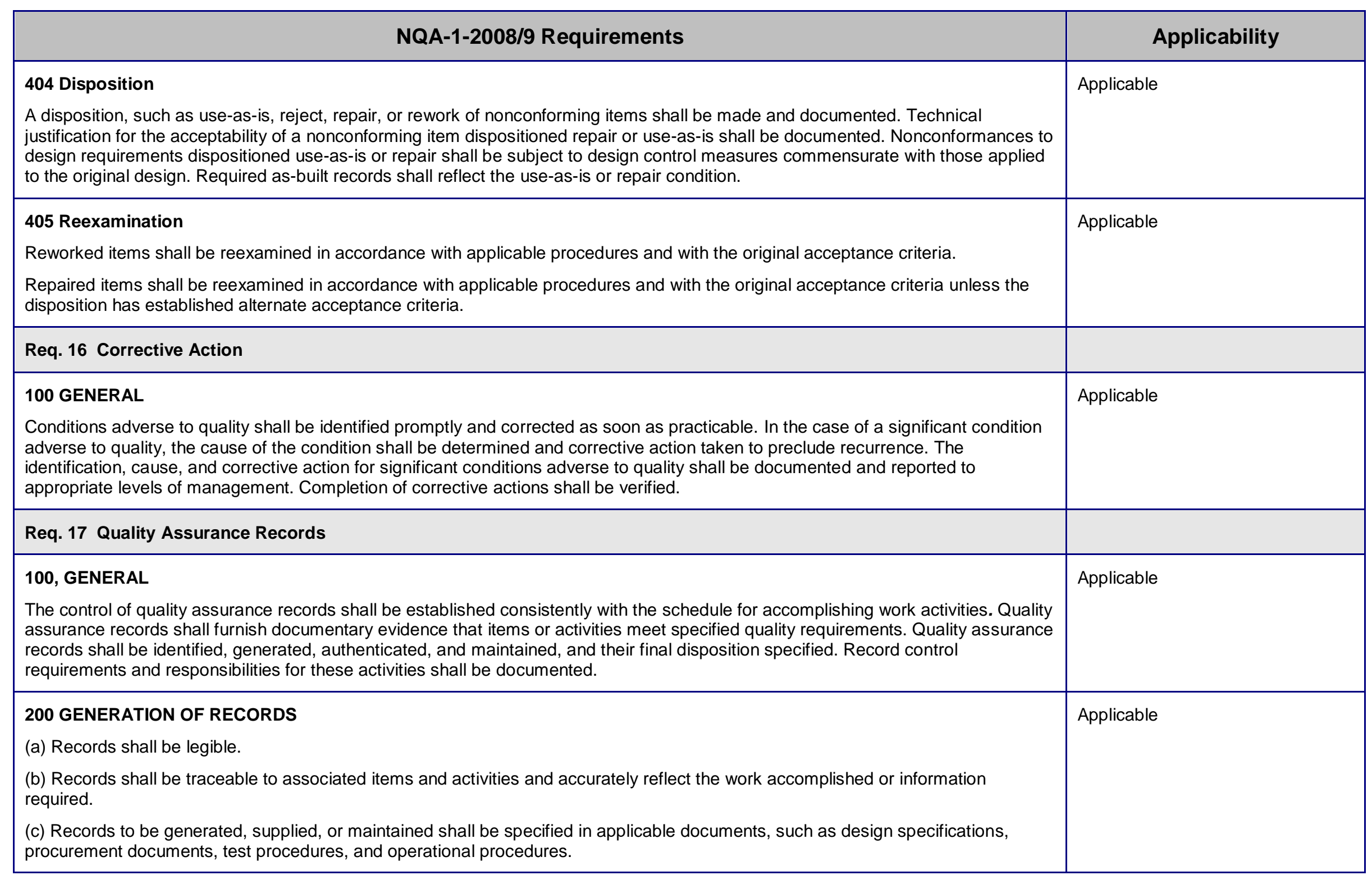




\section{Appendix A: Evaluation of Applicability of NQA-1 to SFR Metallic Fuel Historical Data Qualification Process}

\begin{tabular}{|c|c|}
\hline NQA-1-2008/9 Requirements & Applicability \\
\hline $\begin{array}{l}300 \text { AUTHENTICATION OF RECORDS } \\
\text { (a) Documents shall be considered valid records only if stamped, initialed, or signed and dated by authorized personnel or otherwise } \\
\text { authenticated. Corrections to documents shall be reviewed and approved by the responsible individual from the originating or } \\
\text { authorized organization. } \\
\text { (b) Electronic documents shall be authenticated with comparable information as in para. } 300(a) \text {, as appropriate } \\
\text { (1) with identification on the media; or } \\
\text { (2) with authentication information contained within or linked to the document itself. }\end{array}$ & Applicable \\
\hline $\begin{array}{l}400 \text { CLASSIFICATION } \\
\text { Records shall be classified as lifetime or nonpermanent and maintained by the Owner, or authorized agent, in accordance with the } \\
\text { criteria given in paras. } 401 \text { and } 402 \text { of this Requirement and consistent with applicable regulatory requirements. }\end{array}$ & Applicable \\
\hline $\begin{array}{l}401 \text { Lifetime Records } \\
401.1 \text { Lifetime records are those that meet one or more of the following criteria: } \\
\text { (a) those that would be of significant value in demonstrating capability for safe operation } \\
\text { (b) those that would be of significant value in maintaining, reworking, repairing, replacing, or modifying an item } \\
\text { (c) those that would be of significant value in determining the cause of an accident or malfunction of an item } \\
\text { (d) .those that provide required baseline data for in-service inspections }\end{array}$ & Applicable \\
\hline $\begin{array}{l}\text { 401.2 Lifetime records are required to be maintained for the life of the particular item while it is installed in the plant or stored for } \\
\text { future use. }\end{array}$ & Applicable \\
\hline $\begin{array}{l}402 \text { Nonpermanent Records } \\
\text { Nonpermanent records are those required to show evidence that an activity was performed in accordance with the applicable } \\
\text { requirements but need not be retained for the life of the item because they do not meet the criteria for lifetime records. } \\
\text { Nonpermanent records shall be maintained for the identified retention period. }\end{array}$ & Applicable \\
\hline $\begin{array}{l}500 \text { RECEIPT CONTROL OF RECORDS } \\
\text { Each organization responsible for the receipt of records shall designate a person or organization responsible for receiving the } \\
\text { records. The designee shall be responsible for organizing and implementing receipt controls for permanent and temporary storage. } \\
\text { Receipt controls shall provide a method for identifying the records received, receipt and inspection of incoming records, and } \\
\text { submittal of records to storage. }\end{array}$ & Applicable \\
\hline
\end{tabular}




\section{Appendix A: Evaluation of Applicability of NQA-1 to SFR Metallic Fuel Historical Data Qualification Process}

\begin{tabular}{|c|c|}
\hline NQA-1-2008/9 Requirements & Applicability \\
\hline $\begin{array}{l}600 \text { STORAGE } \\
601 \text { General } \\
\text { (a) Records shall be stored at a predetermined location(s) in facilities, containers, or a combination thereof, constructed and } \\
\text { maintained in a manner that minimizes the risk of loss, damage, or destruction from } \\
\text { (1) natural disasters such as winds, floods, or fires } \\
\text { (2) environmental conditions such as high and low temperatures and humidity } \\
\text { (3) infestation of insects, mold, or rodents } \\
\text { (4) dust or airborne particles } \\
\text { (b) Activities detrimental to the records shall be prohibited in the storage area. } \\
\text { (c) Access to the processing, storage, and retrieval of records shall be limited to authorized personnel. } \\
\text { (d) Provisions shall be made to prevent damage from harmful conditions (such as excessive light, stacking, electromagnetic fields, } \\
\text { temperature, and humidity), as applicable to the specific media utilized for record storage. }\end{array}$ & Applicable \\
\hline $\begin{array}{l}602 \text { Facility Types } \\
\text { There are two equally satisfactory methods of providing storage, single or dual. }\end{array}$ & Applicable \\
\hline $\begin{array}{l}\text { 602.1 Single storage consists of a storage facility, vault, room, or container(s) with a minimum two-hour fire rating. The design and } \\
\text { construction of a single storage facility, vault room, or container shall be reviewed for adequacy by a person competent in fire } \\
\text { protection or contain a certification or rating from an accredited organization. }\end{array}$ & Applicable \\
\hline $\begin{array}{l}\text { 602.2 Dual facilities, containers, or a combination thereof shall be at locations sufficiently remote from each other to eliminate the } \\
\text { chance exposure to a simultaneous hazard. Facilities used for dual storage are not required to satisfy the requirements of para. } \\
602.1 \text {, but shall meet the requirements of para. } 601 \text {. }\end{array}$ & Applicable \\
\hline $\begin{array}{l}603 \text { Temporary Storage } \\
\text { When temporary storage of records (such as for processing, review, or use) is required, the storage facility or container shall provide } \\
\text { a one-hour fire rating, unless dual storage requirements of para. } 602.2 \text { are met. }\end{array}$ & Applicable \\
\hline $\begin{array}{l}700 \text { RETENTION } \\
\text { (a) Record retention periods shall be documented. } \\
\text { (b) Records shall be maintained for their retention periods. }\end{array}$ & Applicable \\
\hline
\end{tabular}




\section{Appendix A: Evaluation of Applicability of NQA-1 to SFR Metallic Fuel Historical Data Qualification Process}

\begin{tabular}{|c|c|}
\hline NQA-1-2008/9 Requirements & Applicability \\
\hline $\begin{array}{l}800 \text { MAINTENANCE OF RECORDS } \\
\text { (a) Records shall be protected from damage or loss. } \\
\text { (b) Record controls shall provide for retrievability within planned retrieval times based upon the record type or content. } \\
\text { (c) The methods for record changes shall be documented. } \\
\text { (d) Provisions shall be established to ensure that no unacceptable degradation of the electronic record media occurs during the } \\
\text { established retention period. } \\
\text { (e) Provisions shall be made to ensure that the records remain retrievable after hardware, software, or technology changes. } \\
\text { (f) Provisions shall be established to ensure the following when records are duplicated or transferred to the same media or to a } \\
\text { different media for the purposes of maintenance or storage: } \\
\text { (1) duplication or transfer is appropriately authorized } \\
\text { (2) record content, legibility, and retrievability are maintained }\end{array}$ & Applicable \\
\hline Req. 18 Audits & \\
\hline $\begin{array}{l}100 \text { GENERAL } \\
\text { Audits shall be performed to verify compliance to quality assurance program requirements, to verify that performance criteria are } \\
\text { met, and to determine the effectiveness of the program. These audits shall be performed in accordance with written procedures or } \\
\text { checklists by personnel who do not have direct responsibility for performing the activities being audited. Audit results shall be } \\
\text { documented and reported to and reviewed by responsible management. Follow-up action shall be taken where indicated. }\end{array}$ & Applicable \\
\hline $\begin{array}{l}200 \text { SCHEDULING } \\
\text { Audits shall be scheduled in a manner to provide coverage and coordination with ongoing activities, based on the status and } \\
\text { importance of the activity. Scheduled audits shall be supplemented by additional audits of specific subjects when necessary to } \\
\text { provide adequate coverage. }\end{array}$ & Applicable \\
\hline 300 PREPARATION & \\
\hline $\begin{array}{l}301 \text { Audit Plan } \\
\text { The auditing organization shall develop an audit plan for each audit. This plan shall identify the audit scope, requirements, audit } \\
\text { personnel, activities to be audited, organizations to be notified, applicable documents, schedule, and written procedures or } \\
\text { checklists. }\end{array}$ & Applicable \\
\hline
\end{tabular}




\section{Appendix A: Evaluation of Applicability of NQA-1 to SFR Metallic Fuel Historical Data Qualification Process}

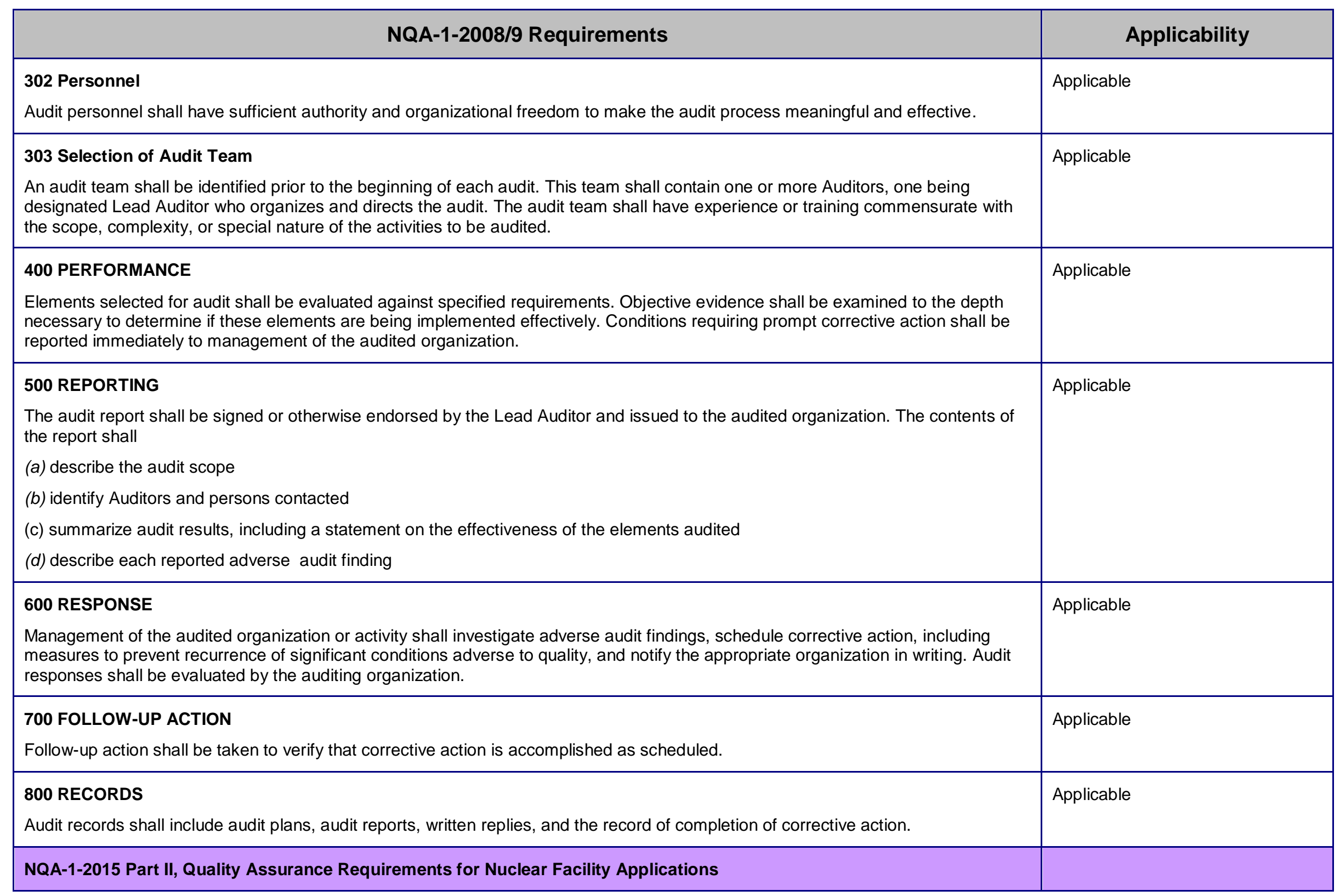




\section{Appendix A: Evaluation of Applicability of NQA-1 to SFR Metallic Fuel Historical Data Qualification Process}

\begin{tabular}{|c|c|}
\hline NQA-1-2008/9 Requirements & Applicability \\
\hline Subpart 2.7, Quality Assurance Requirements for Computer Software for Nuclear Facility Applications & \\
\hline $\begin{array}{l}100 \text { GENERAL } \\
\text { Subpart } 2.7 \text { provides requirements for the acquisition, development, operation, maintenance, and retirement of software. The } \\
\text { appropriate requirements of this Subpart shall be implemented through the policies, procedures, plans, specifications, or work } \\
\text { practices, etc., that provide the framework for software engineering activities. Subpart } 2.7 \text { supplements the requirements of Part I } \\
\text { and shall be used in conjunction with applicable Requirements of Part I when and to the extent specified by the organization invoking } \\
\text { the Subpart. }\end{array}$ & Applicable \\
\hline $\begin{array}{l}101 \text { Software Engineering } \\
\text { The scope of software engineering activities include the following elements, as appropriate: } \\
\text { (a) software acquisition method(s) for controlling the acquisition process for software and software services } \\
\text { (b) software engineering method(s) used to manage the software life-cycle activities } \\
\text { (c) application of standards, conventions, and other work practices that support the software life cycle } \\
\text { (d) controls for support software used to develop, operate, and maintain computer programs }\end{array}$ & Applicable \\
\hline $\begin{array}{l}200 \text { GENERAL REQUIREMENTS } \\
\text { The following general requirements shall be applied to the software engineering elements described in para. } 101 \text { of this Subpart. }\end{array}$ & Applicable \\
\hline $\begin{array}{l}201 \text { Documentation } \\
\text { The appropriate software engineering elements, described in para. } 101 \text { of this Subpart, shall define the baseline documents that are } \\
\text { to be maintained as records, in accordance with Part I, Requirement } 17 \text {. Although multiple documentation requirements are specified } \\
\text { within this Subpart, they can be provided as separate or as combined documents. }\end{array}$ & Applicable \\
\hline $\begin{array}{l}202 \text { Review } \\
\text { The appropriate software engineering elements, described in para. } 101 \text { of this Subpart, shall define the control points and associated } \\
\text { reviews. Reviews of software shall ensure compliance with the approved software design requirements. Although multiple review } \\
\text { requirements are specified within this Subpart, the reviews may be performed and documented separately or combined, as } \\
\text { appropriate, to the defined software engineering method. } \\
\text { The following two reviews are required: } \\
\text { (a) One review shall consider the requirements related to the activities of preparing the computer program for acceptance testing. } \\
\text { This review can be combined with or be part of the software design verification. } \\
\text { (b) The other review shall provide assurance of the satisfactory completion of the software development cycle including acceptance }\end{array}$ & Applicable \\
\hline
\end{tabular}




\section{Appendix A: Evaluation of Applicability of NQA-1 to SFR Metallic Fuel Historical Data Qualification Process}

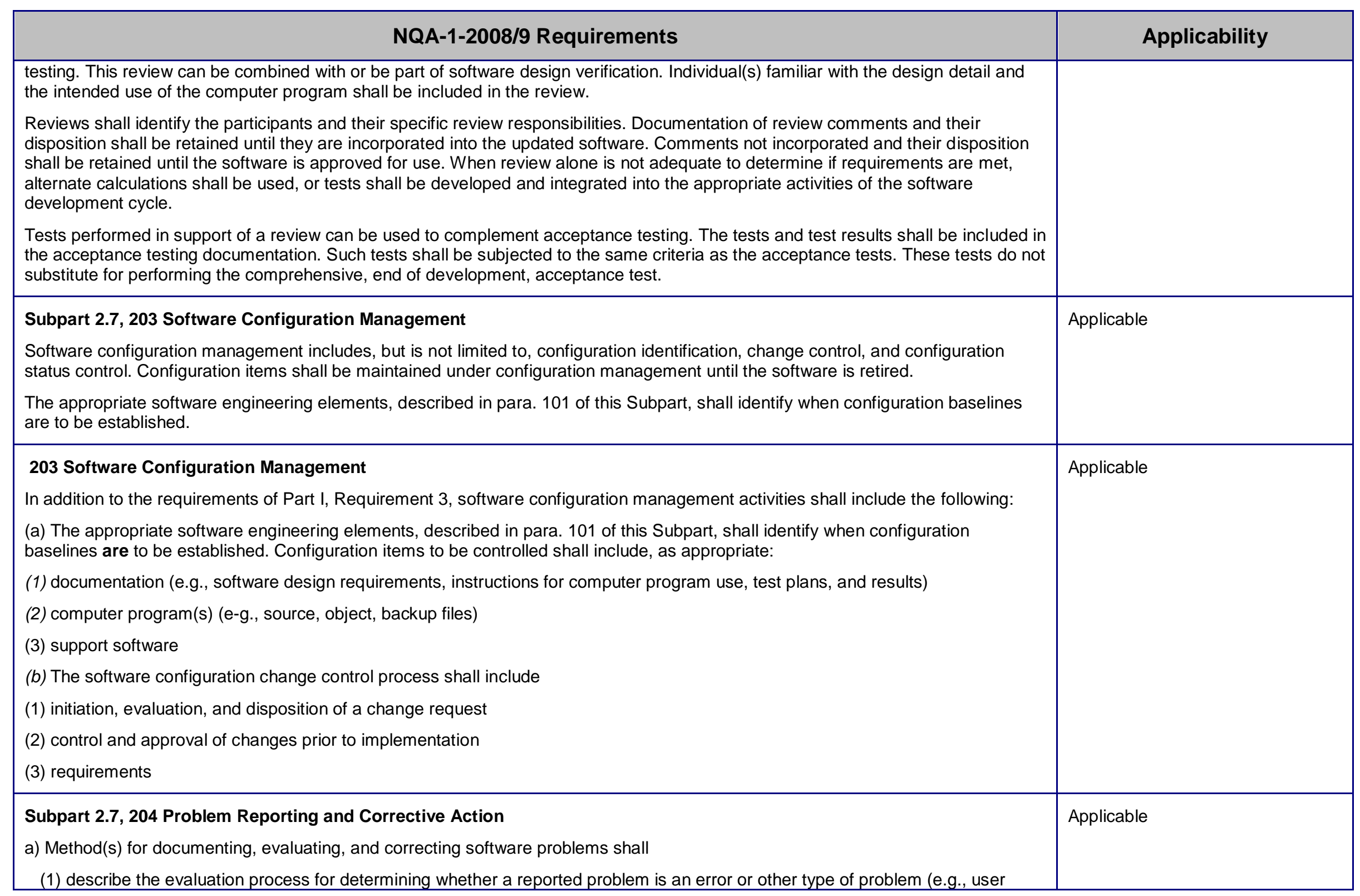




\section{Appendix A: Evaluation of Applicability of NQA-1 to SFR Metallic Fuel Historical Data Qualification Process}

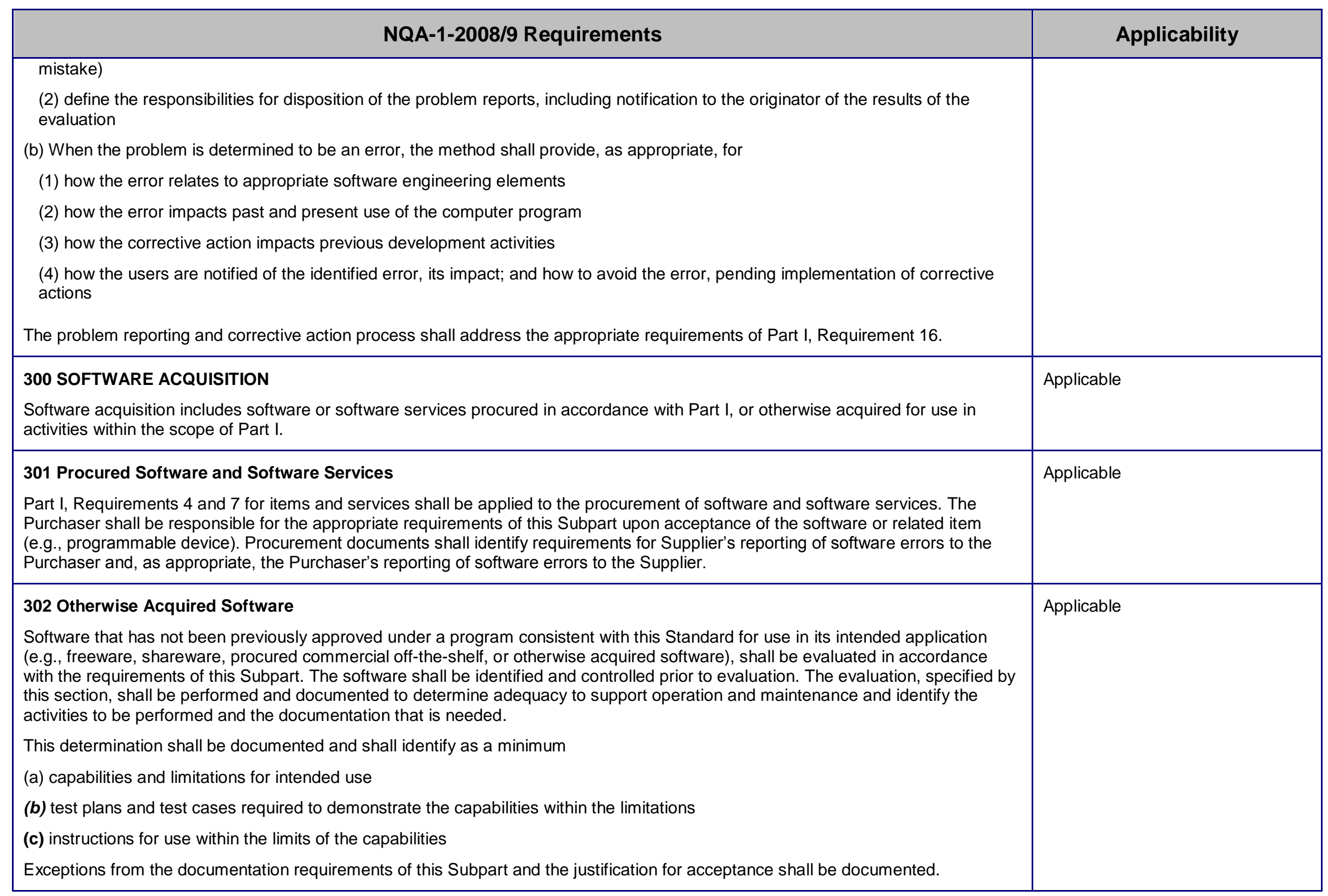




\section{Appendix A: Evaluation of Applicability of NQA-1 to SFR Metallic Fuel Historical Data Qualification Process}

\begin{tabular}{|c|c|}
\hline NQA-1-2008/9 Requirements & Applicability \\
\hline $\begin{array}{l}\text { The results of the above evaluation and the performance of the actions necessary to accept the software shall be reviewed and } \\
\text { approved. The resulting documentation and associated computer program(s) shall establish the current baseline. } \\
\text { Revisions to previously baseline software received from organizations not required to follow this Subpart shall be evaluated in } \\
\text { accordance with this section. }\end{array}$ & \\
\hline $\begin{array}{l}400 \text { SOFTWARE ENGINEERING METHOD } \\
\text { Software engineering method(s) shall be documented. The selected software engineering method shall ensure that software life } \\
\text { cycle activities are planned and performed in a traceable and orderly manner. } \\
\text { The software design process shall be documented, approved by the responsible design organization, and controlled. This process } \\
\text { shall include the activities described in paras. } 401 \text { through } 404 \text {. }\end{array}$ & Applicable \\
\hline $\begin{array}{l}401 \text { Software Design Requirements } \\
\text { Software design requirements shall specify technical and software engineering (i.e., para. } 101 \text { of this Subpart) requirements, } \\
\text { including security features (e.g., vulnerability protection, and cyber-security). Identify applicable reference drawings, specifications, } \\
\text { codes, standards, regulations, procedures, or instructions that establish software design requirement test, inspection, and } \\
\text { acceptance criteria. Security requirements shall be specified commensurate with the risk from unauthorized access or use The } \\
\text { software requirements shall identify the operating system, function, interfaces, performance requirements, installation considerations, } \\
\text { design inputs, and any design constraints of the computer program. Software design requirements shall be traceable throughout the } \\
\text { software life cycle. }\end{array}$ & Applicable \\
\hline $\begin{array}{l}402 \text { Software Design } \\
\text { An integral part of software design is the design of a computer program that is part of an overall system. Thus, the software design } \\
\text { shall consider the computer program's operating environment. Measures to mitigate the consequences of problems, as identified } \\
\text { through analysis, shall be an integral part of the design. These potential problems include external and internal abnormal conditions } \\
\text { and events that can affect the computer program. } \\
\text { The software design shall be documented and shall define the computational sequence necessary to meet the software } \\
\text { requirements. The documentation shall include, as applicable, numerical methods, mathematical models, physical models, control } \\
\text { flow, control logic, data flow, process flow, data structures, process structures, and the applicable relationships between data } \\
\text { structures and process structures. This documentation may be combined with the documentation of the software design } \\
\text { requirements or the computer program listings resulting from implementation of the software design. }\end{array}$ & Applicable \\
\hline $\begin{array}{l}\text { 402.1 Software Design Verification. } \\
\text { Software design verification shall evaluate the technical adequacy of the design approach and ensure internal completeness, } \\
\text { consistency, clarity, and correctness of the software design and shall verify that software design is traceable to the software design } \\
\text { requirements. Software design verification shall include review of test results. The software design verification shall be completed } \\
\text { prior to approval of the computer program for use. The requirements for the software design verification activity shall be documented } \\
\text { in the software engineering method. }\end{array}$ & Applicable \\
\hline
\end{tabular}




\section{Appendix A: Evaluation of Applicability of NQA-1 to SFR Metallic Fuel Historical Data Qualification Process}

\begin{tabular}{|c|c|}
\hline NQA-1-2008/9 Requirements & Applicability \\
\hline $\begin{array}{l}403 \text { Implementation } \\
\text { The software design shall be translated into computer program(s) using the programming organization's or design organization's } \\
\text { programming standards and conventions. } \\
\text { The implementation process shall result in software products such as computer program listings and instructions for computer } \\
\text { program use. A review shall be performed in accordance with para. } 202 \text { of this Subpart. }\end{array}$ & Applicable \\
\hline $\begin{array}{l}404 \text { Acceptance Testing } \\
\text { The acceptance testing activity shall demonstrate that the computer program adequately and correctly performs all intended } \\
\text { functions (i.e., specified software design requirements). Computer program tests including, as appropriate, software design } \\
\text { verification, factory acceptance tests, site acceptance tests, and in-use tests shall be controlled. } \\
\text { Test requirements and acceptance criteria for computer programs shall be provided by the organization responsible for the use of } \\
\text { the computer program and shall include the following, as applicable: } \\
\text { (a) Software design verification testing shall demonstrate the capability of the computer program(s) to provide valid results for test } \\
\text { problems encompassing the range of documented permitted usage. } \\
\text { (b) Computer program acceptance testing shall consist of the process of exercising or evaluating a system or system component by } \\
\text { manual or automated means to ensure that it satisfies the specified requirements and to identify differences between expected and } \\
\text { actual results in the operating environment. } \\
\text { (c) In-use computer programs testing shall demonstrate required performance over the range of operation of the controlled function } \\
\text { or process. }\end{array}$ & Applicable \\
\hline $\begin{array}{l}404 \text { Acceptance Testing. } \\
\text { Acceptance testing shall demonstrate, as appropriate, that the computer program } \\
\text { (a) properly handles abnormal conditions and events as well as credible failures } \\
\text { (b) does not perform adverse unintended functions } \\
\text { (c) does not degrade the system either by itself, or in combination with other functions or configuration items } \\
\text { Acceptance testing shall be performed prior to approval of the computer program for use. Configuration items shall be under } \\
\text { configuration change control prior to starting acceptance testing. Acceptance testing shall be planned and performed for all software } \\
\text { design requirements. Acceptance testing ranges from a single test of all software design requirements to a series of tests performed } \\
\text { during computer program development. Performance of a series of tests provides assurance of correct translation between activities } \\
\text { and proper function of individual modules. Testing shall include a comprehensive acceptance test performed in the operating } \\
\text { environment prior to use. } \\
\text { The test plans, test cases, and test results shall be documented, reviewed, and approved prior to use of the computer program in } \\
\text { accordance with Part I, Requirement 11. Observations of unexpected or unintended results shall be documented and dispositioned }\end{array}$ & Applicable \\
\hline
\end{tabular}




\section{Appendix A: Evaluation of Applicability of NQA-1 to SFR Metallic Fuel Historical Data Qualification Process}

\begin{tabular}{|c|c|}
\hline NQA-1-2008/9 Requirements & Applicability \\
\hline $\begin{array}{l}\text { prior to test result approval. } \\
\text { The acceptance testing of changes to the computer program shall be subjected to selective retesting to detect unintende } \\
\text { effects introduced during the change. Such testing shall provide assurance that the changes have not caused unintendec } \\
\text { effects in the computer program, and to verify that a modified system(s) or system component(s) still meets specified soft } \\
\text { design requirements }\end{array}$ & \\
\hline $\begin{array}{l}405 \text { Operation } \\
\text { After the software is approved for use and installed in the operating environment, the use of the software shall be control } \\
\text { accordance with approved procedures and instructions. These include, as appropriate } \\
\text { (a) application documentation (e.g., application log) } \\
\text { (b) access control specifications } \\
\text { (c) computer system vulnerability protections } \\
\text { (d) problem reporting and corrective action } \\
\text { (e) in-use tests } \\
\text { (f) the configuration change control process }\end{array}$ & Applicable \\
\hline $\begin{array}{l}406 \text { Maintenance } \\
\text { The appropriate software engineering elements, as described in para. } 101 \text { of this Subpart, shall identify how changes to t } \\
\text { are controlled. Typically, changes are in response to any of the following: } \\
\text { (a) enhancement requests from the user community } \\
\text { (b) revisions to software based on software design requirements } \\
\text { (c) changes to the operating environment and changes to computer system vulnerability protections } \\
\text { (d) reported software problems that must be corrected }\end{array}$ & Applicable \\
\hline $\begin{array}{l}407 \text { Retirement } \\
\text { During retirement, support for the software product is terminated, and the routine use of the software shall be prevented. }\end{array}$ & Applicable \\
\hline
\end{tabular}




\section{Appendix A: Evaluation of Applicability of NQA-1 to SFR Metallic Fuel Historical Data Qualification Process}

\begin{tabular}{|c|c|}
\hline NQA-1-2008/9 Requirements & Applicability \\
\hline $\begin{array}{l}500 \text { STANDARDS, CONVENTIONS, AND OTHER WORK PRACTICES } \\
\text { As appropriate, the software engineering method, software acquisition method, or both shall establish the need for standards, } \\
\text { conventions, and other required work practices to facilitate software life cycle activities (e.g., software design and implementation } \\
\text { activities). Standards, conventions, and other required work practices shall be documented. }\end{array}$ & Applicable \\
\hline $\begin{array}{l}600 \text { SUPPORT SOFTWARE } \\
\text { Support software includes software tools and system software. As appropriate, the software engineering method, software } \\
\text { acquisition method, or both shall establish the need for software tools. }\end{array}$ & Applicable \\
\hline $\begin{array}{l}601 \text { Software Tools } \\
\text { Software tools shall be evaluated, reviewed, tested, and accepted for use, and placed under configuration control as part of the } \\
\text { software development cycle of a new or revised software product. Software tools that do not affect the performance of the software } \\
\text { need not be placed under configuration control. } \\
\text { In cases involving modifications of software products using the software tools, the configuration of the support software associated } \\
\text { with that modification shall be managed. Changes to the software tool shall be evaluated for impact on the software product to } \\
\text { determine the level of reviews and retesting that will be required. }\end{array}$ & Applicable \\
\hline $\begin{array}{l}602 \text { System Software } \\
\text { System software consists of the on-line computer programs used to provide basic or general functionality and facilitate the operation } \\
\text { and maintenance of the application computer program. Examples include lower level software layers, assemblers, interpreters, } \\
\text { diagnostics, and utilities. } \\
\text { System software shall be evaluated, reviewed, tested, and accepted for use as part of the software development cycle of a new or } \\
\text { revised software product. System software shall be placed under configuration change control. Changes to the system software shall } \\
\text { be evaluated for impact on the software product to determine the level of reviews and retesting that will be required. }\end{array}$ & Applicable \\
\hline
\end{tabular}


Argonne

\section{Nuclear Engineering Division}

Argonne National Laboratory

9700 South Cass Avenue, Bldg. 208

Argonne, IL 60439

www.anl.gov 